\title{
THE SPECIAL NATURE OF THE WAGE-EARNER'S LIFE INSURANCE PROBLEM ${ }^{1}$
}

\author{
L. L. FULIER*
}

The assumption that the wage-earner's life insurance problem has a special nature need not derive from any sentimental concern for the welfare of the "lower classes." A distinction between economic classes is institutionally imbedded in the business of insurance itself. It forms the basis for an enormous branch of that business, Industrial insurance-a branch which now has outstanding policies totalling in their death benefits more than seventeen billion dollars. For this reason a symposium on the problem of the wage-earner's life insurance can hardly be regarded as falling in the class of those discussions which create for the first time the "problems" toward the solution of which they purport to be directed. The problem of the wage-earner's life insurance exists and is being attacked every day by the insurance companies-whether symposia are written about it or not.

What is attempted in this article is an analysis of the ways in which the problem of providing suitable life insurance for the wage-earning classes differs from the problem of providing suitable life insurance for those possessing higher incomes. The discussion will not be confined to the mechanics of distributing life insurance

${ }^{1} \mathrm{~A}$ word or two might be appropriate concerning the circumstances under which this article came to be written. In the editorial planning of the symposium an effort was, of course, made to secure a wellrounded discussion which, in one way or another, would touch on all the more obviously significant aspects of the general subject. It was, howvever, impossible to be certain in advance that this object would be achieved. Some risk of incompleteness is inherent in the symposium form. When the other articles were all in his hands the special editor felt that they left insufficiently explaincd the law and practice of Industrial insurance. Though this hiatus was due in no sense to the fault of other contributors, it was felt that it impaired the usefulness of the symposium for the general reader. In consequence this article, originally planned as a short introduction to the symposium, was expanded in an attempt to fill the breach. Since it was prepared in some haste it can make no pretense to scholarly thoroughness.

The statements concerning insurance practice are made on the basis of a variety of sources of information. Personal visits to insurance offices, correspondence with insurance officials and insurance commissioners, the writer's own inferences, have all contributed to the result. Most of the statements which purport to describe definite and existing practices are believed to be accurate though there was, in vicw of the haste with which the article was prepared, some possibility of misinterpretation or mistaken inference.

A number of persons actively engaged in the insurance business have been very helpful, and it is a source of regret to the writer that it seems inadvisable to identify here those to whom he is indebted, since to do so might invite erroneous inferences concerning the derivation of particular statements.

- A.B., 1924, J.D., 1926, Stanford University. Professor of Law, Duke University, since 1931. Special Editor of this issue of Law and Contemporary Problems. Contributor to legal periodicals. 
protection, but will take into account problems which may be regarded as inevitable by-products of that process-for example, the problem of an adequate and just disposition of disputes. Throughout I have made an attempt to separate those factors which are intrinsic in the wage-earner's position from those which may result from the present practices of the insurance companies. For example, I have raised the question whether the weekly premium collection in the home is a necessary feature of any scheme of wage-earner's insurance or merely has that appearance because it is institutionalized in the practice of the Industrial companies. It is obvious that a question of this sort necessarily implies an appraisal of existing company practices. Even in an article which purports to be primarily analytical-as this one does-it is impossible entirely to separate analysis from criticism. In one or two instances I have not hesitated to go completely beyond the scope of analysis for the purpose of making concrete suggestions for reform.

As was pointed out in the Foreword the term "wage-earner" is not here used in any technical or restrictive sense. The reader may substitute for it, if he wishes, "lower income classes," "working classes," "the underprivileged," or simply "the poor"-whichever accords with his tastes or prejudices-remembering always that we do not refer to a submerged minority but to a class large enough to include about half our population. It should be emphasized that the line of division implied is economic, not "social." This does not mean that a realistic account of the special insurance problems of the lower economic groups can ignore the fact that differences in money income may result in, or be associated with, differences in social customs and intellectual training. Because insurance as an institution intimately concerns the personal life of the insured and particularly his family life, these collateral consequences of wealth-or the lack of it-must be taken into account. Any attempt, prompted by an impulse of euphemism, to gloss over the importance of economic distinctions would be out of place in an analysis of this sort. ${ }^{2}$

\section{The Cost of the Wage-Earner's Insurance}

The problem of the cost of wage-earner's insurance has been raised principally in connection with Industrial insurance. It is generally admitted that this type of insurance costs more than Ordinary insurance though opinions differ as to just how much more it costs. The difficulty arises, as Professor Oglesby shows in his article, ${ }^{3}$ from the fact that there are various methods of calculating the cost.

One insurance official has calculated that "it is possible to secure at the outset, on the average, 39 per cent more standard Ordinary insurance than Industrial for

2One further possible source of misunderstanding should perhaps be anticipated. It is unfortunately true that one cannot speak of a "wage-earning class" without implying a fixity of outline and an identy of interest for which there exists no real counterpart in the actual social world. In this article I should like it understood that the terms "wage-earner," "lower economic classes," and the like are used as convenient ellipses for a reality much more complex and fluid than that which they seem, standing alone, to imply. The ambiguity of these terms is such that one might with some justification attempt a redefinition of them for each new aspect of the problem discussed. This is, however, scarcely practicable.

"The Case Against Government Life Insurance, infra at p. I29. 
an identical initial premium." ${ }^{4}$ But, unfortunately-from the standpoint of one attempting to compute the cost of insurance-we cannot assume that the policyholder will die as soon as he buys his policy. Various things may happen to him and his policy which complicates our calculations. Two things are, however, clear: (x) The additional cost of Industrial over Ordinary insurance decreases if the policyholder lives and keeps his policy, so that the longer his policy is in force the more nearly on a parity he becomes with the Ordinary policyholder. This is because, in the better Industrial companies at any rate, dividends are higher than in the Ordinary branch. ${ }^{6}$ (2) On the other hand the lapse rate in Industrial insurance is higher than in Ordinary. This means that there is a greater likelihood that the premium payments of the Industrial policyholder will turn out to be-for him as an individual at any rate-an outright loss. ${ }^{\natural}$

Dr. Taylor offers certain figures relevant to the cost of Industrial insurance which eliminate the difficulty involved in computing the direct cost to the policyholder. He calculates that for every dollar paid in premiums between Igrr and 1932, Industrial policyholders received in various forms (death claims, matured endowments, dividends, disability benefits and cash surrender values) 45 cents. The Ordinary policyholder received, on the other hand, 68 cents. $^{7}$ These figures, of course, ignore the amount held in reserve which should properly be included. Taking the same years and adding the amount held in reserve the Industrial policyholder's dollar "realized" 84 cents. The corresponding figure for Ordinary insurance is $\$ 1.07 .^{8}$ Another relevant calculation is the following. In 1932, I9.6 cents out of every dollar paid for Industrial insurance went for salaries and commissions, as compared to I2.8 in the Ordinary branch. ${ }^{9}$

In what follows I have attempted to answer the question: To what extent is a higher cost intrinsic in any form of unsubsidized insurance for the wage-earner?

\section{The Economic Disadvantages of Being Poor.}

When one attempts to analyze what it is that distinguishes the lower economic classes from other classes he very soon arrives at the conclusion that it lies chiefly in the fact that they have less money. As applied to insurance this means that they can buy less insurance. This in turn explains why it is that they must pay proportionately more for the insurance they do buy. In this, insurance does not differ from any other commodity. The man who is able to buy a bushel of potatoes is likely to get a better price than the man who is able to buy only a pound. An analysis of the

\footnotetext{
'Kineke, Some Aspects of Modern Industrial Insturance (1932), 21 THE REcond, AM. INST. OF Actuaries, 23, 28.

${ }^{8}$ Ibid.

"If we parallel the two sets of policies on the basis of the much more common experience of policy termination by surrender rather than by death or maturity, the Industrial policyholder is found to be incomparably worse off than his Ordinary brother." TAYLOR, THE SOcIal. CosT OF Industrial Insurance (1933) 183 .

${ }^{7} I d$. at $34 \mathrm{I}$.

${ }^{8}$ Ibid.

${ }^{\circ} I d$. at 339.
} 
reasons why this is true is hardly called for here. It will suffice to point out that the proportion of the cost of insurance appropriated to "overhead" normally increases as the size of the policy decreases, unless some change in the manner of handling small policies intervenes to counteract this tendency. Even where economies are effected in the administration of small policy business, as through the elimination of the medical examination and loans on reserve values, ${ }^{10}$ the fact that certain expenses (e.g. those connected with routine office records) remain relatively fixed prevents these economies from counteracting the general tendency of overhead to weigh more heavily on the small policy.

In a sense the Industrial policyholder suffers from the division of the insurance business into Industrial and Ordinary. Many businesses knowingly sell services or commodities in petty quantities at a loss, because it is impracticable to establish a differential scale of prices or because it is feared that to do so might arouse resentment. In such cases the large purchaser is an unwitting subsidizer of the small purchaser. If it were not for the separation of the insurance business into branches the small policyholder might conceivably enjoy a similar subsidy, as, indeed, the holder of the minimum Ordinary policy (usually $\$ 1000$ ) does to some extent under the present system. But it is, of course, quite unlikely that this division of the insurance business will be undone. If anything, business reform may be expected to take the direction of making each branch of the business pay its own way-something which usually, though not always, works to the disadvantage of the little fellow.

\section{Wage-earner's Insurance and the Death Rate}

The mortality experience among Industrial policyholders has been considerably higher than that in the Ordinary branch. As a crystallization of this experience there exists a Standard Industrial Mortality Table. ${ }^{11}$ If it is true that this difference in the death rate is due to the conditions under which the Industrial policyholder lives, ${ }^{12}$ or conceivably, to a difference in native physical endowment, ${ }^{13}$ then-so long as he is unassisted by a subsidy and his insurance constitutes a separate branch of the business-the wage-earner will have to pay a higher price for his insurance. An improvement in the general standard of life, or a spread of the knowledge of the principles of hygiene, may, of course, to some extent alleviate the wage-earner's disadvantage in this respect. ${ }^{14}$

The higher mortality in the Industrial branch is, of course, contributed to by the fact that Industrial policies are ordinarily issued without medical examination.

The companies do not make loans on Industrial policies chiefly because of the disproportionate cost which would be involved in keeping track of small advances, but also perhaps because of a feeling that to grant such loans might be to tempt the prodigal.

II TAYLOR, op. cit. supra note 6, at $\mathrm{r} 6 \mathrm{r}$.

12 WoOds, THE Soctologr OF Life Insurance (1928) 106.

${ }^{13}$ See the comments on the relation between occupation and mortality in TAyLor, op. cit. supra note 6, at 57-58, referring to the studies of Dr. Dublin.

24 Certain of the companies, notably the Metropolitan and the John Hancock, spend large sums on fiealth and welfare work. See $i d$. at 275-296. 
Since this method of underwriting probably effects a net economy in the conduct of the business, the extent to which the death rate in Industrial insurance is increased by its non-medical character can be ignored in a discussion of the cost of insurance. On the other hand, if the companies neglect inexpensive non-medical safeguards against bad underwriting, or, worse yet, if their practices and methods of compensating agents encourage bad underwriting, then the worker may justly complain that he pays too much for his Industrial policy.

In the matter of selecting risks the plain fact is that in the Industrial branch the sole judge of the applicant's fitness for insurance is ordinarily the agent, an untrained and poorly-paid individual whose earnings depend on "keeping his debit on increase." The danger here involved is well known to the companies. An official of one of the southern Industrial companies said in an address before the Industrial Insurer's Conference:

"With my company as with many Industrial insurance companies which originally started with the weekly health and accident business, ${ }^{15}$ inspections in the past were not given their proper place in the company's underwriting. Applications were written without the agents seeing the risks; in many cases the information given on the application was furnished by the beneficiary, who in most cases attended to the payment of the premiums, and who was vitally interested in collecting the claim. Applications were written without requiring any signature other than that furnished by the agent writing the business. I have heard many old-time underwriters say that they would be perfectly willing to do away with the application entirely and write all business from a list of names, ages and premiums furnished by the agent....

"On one debit where we inspected ten policies that had been in force for three months we found that out of this ten, six were in bad health at the time they were written, one of them being in a hospital in an adjoining city and about to die. This was an extreme case of bad underwriting." 16

In combatting this evil some of the smaller companies have resorted to the practice of employing an independent agency (usually a credit organization) to investigate their risks. A report of the results of one such investigation is worthy of quotation:

"An analysis of ... I,00o Industrial inspection reports brought out the following information: $12 \%$ of the applicants were not aware of the insurance; $18 \%$ of the applications were signed by persons other than the applicant; $7 \%$ of the cases showed a discrepancy in age; $x 3 \%$ disclosed definitely unfavorable health of the applicant. . . .

"[One case involves] a negro whose age, as given by the company, is 50. Our inspector reports from a personal interview that this man is 85 years old and looks it; that he is very decrepit, suffers from rheumatism, and that both legs were swollen at the time of the interview. It is further stated that his daughter, the beneficiary, took out the insurance without the knowledge of the old man and our inspector remarks that the policyholder will not live six months." 17

Is Author's note: A great many of the smaller companies doing business principally in the Middle West and South developed out of concerns which originally did only a health and accident business. This origin has to some extent affected their standards and practices.

${ }^{16}$ Address of Mr. W. R. Lathrop reported in Industrial Insurance, November, 1933, p. 9 and p. 20.

${ }^{17}$ Smith, Inspection Reports on Industrial Applicants, Industrial InsUrance, September, 1931, p. 5. 
One might be inclined to conclude from this evidence that the higher mortality experience of the Industrial companies may be due to their own lax methods rather than to the fact that the wage-earner fails to get enough vitamins. ${ }^{18}$ However, several things may be said in defense of the companies. First, the practices mentioned above are not necessarily typical of all companies, and it is significant that in each case the facts were revealed as the result of an effort to correct existing abuses. It must, however, be admitted that there is a limit to what can be accomplished by inspection and supervision and that even the best run companies are, in the matter of selecting risks, to some extent at the mercy of their agency forces. Secondly, whatever steps are taken to correct this evil will, in all likelihood, cost money and this cost will be charged to the policyholder. ${ }^{19}$ Thirdly, the present lax system does often provide for the man who would otherwise be deprived of insurance, i. e. the sub-standard risk-even if it lets in with him an occasional swindler and charges the cost of both to the honest and healthy policyholder. Fourthly, not all of the bad risks accepted by the agent mean a loss to the company. The company, relying on the warranty of sound health contained in the policy, may refuse to pay the death benefit in cases of patent fraud and may even bring a suit to have the policy cancelled during the life of the insured. Of course, there is normally a time limitation on this privilege of the company imposed by the policy itself. Because the reputation of failing to meet policy claims is a very injurious one for any company, the companies are somewhat reluctant to take advantage of this method of reducing the loss occasioned by bad risks. Nevertheless this method of undoing the effects of bad underwriting and thwarting fraudulent claims is a significant factor in reducing the cost of Industrial insurance, at least through its moral effects in discouraging the speculator. ${ }^{20}$

28 The higher mortality rate among Industrial policyholders may also be due in part to an adverse selection of risks arising out of the high lapse rate in that form of insurance. TAYzor, op. cit. supra note 6 , at 164 . The mortality rate is also increased by the fact that a greater percentage of female lives are insured under industrial policies.

${ }^{10}$ One insurance official estimates that a thorough examination of each risk would require at least the work of one investigator for half a day. He goes on to say, "If we pay our investigators $\$ 30$ a week, handled 12 cases a week, we have $\$ 2.50$ a claim. The Prudential therefore, would be paying $\$ 10,000,000$ a year additional to investigate these policies, some of which would have a five cent premium, and no more, paid on them. That would be an impossible situation as anyone can see." Statement of James F. Little, Hearing before the Sub-Committee on Instrance and Banks of the Committee on the District of Columbia, United States Senate, on S. 1903, 71st. Cong., 3rd. Sess., Dec. 19, 1930, p. 90. (The report of this hearing, occupying $3^{\circ}$ pages, is a mine of information, and misinformation, concerning Industrial insurance.)

${ }^{30}$ At one time one of the large insurance companies writing Ordinary insurance experimented with a folicy which was incontestable from the date of its issue. It experienced a very high mortality and suffered severe losses in consequence. Of course, the experience of this one company does not mean that the same thing would happen if all companies adopted the plan simultaneously, since this company undoubtedly attracted bad risks by the fact that its policy offered them a peculiar advantage. On, the other hand, the general adoption of a policy incontestable from issue might lead to a great increase in speculative insurance, already a very serious evil in the Industrial branch. ("Speculative insurance" refers to the situation where one person pays premiums on the life of another in the hope of an early return on his investment-a hope usually justified by the condition of the insured.) 


\section{The Cost of Selling and Service}

The cost of insurance includes a selling cost. Even the man who is eager to buy insurance and would gladly have gone to a central bureau and made application for it-if there is such a man-has to pay for being "sold." Part of his premiums go, directly or indirectly, to the agent as a commission for effecting the sale. Though there are important differences between Industrial and Ordinary insurance in the manner in which the agent's compensation is computed, ${ }^{21}$ there is no denying the fact that in both systems one of the major activities of the company's personnel consists in "production," i.e. the selling of new policies, and that this activity is financed by the policyholder. The effect in both systems is that the man who is hard to sell, who requires repeated visits and tho application of some of the more recondite principles of salesmanship, really receives a service for which he fails to pay the full cost. His insurance is partially subsidized at the expense of the willing purchaser. Whether there could be devised some more equitable or less expensive method of overcoming sales resistance is a problem which lies beyond the scope of this paper. Professor Oglesby argues from the experience of foreign governments that agents and salesmanship are necessary to the success of any kind of life insurance. ${ }^{22}$

But the Industrial policyholder not only pays the expense of effecting the initial sale; he pays for a subsequent service which is unknown to the holder of Ordinary insurance. With only the aid of a very distastefully phrased printed reminder the Ordinary policyholder must on his own initiative scrape together his premium payments once, twice, or four times a year and mail them off to the company. The Industrial policyholder, on the other hand, enjoys the luxury of a weekly visit to his home where the premiums are taken from him in painless driblets. This service necessarily costs something and the policyholder pays for it, though how much he pays is again a matter of dispute.

Is the weekly premium collection at the home a permanent and intrinsic feature of wage-earner's insurance? The Industrial companies generally assume that it is. Not only is their business conducted on the assumption that premiums will ordinarily be collected at the home but it is the official policy of some companies to discourage in every way possible "office pays." 23

The following arguments have been, or may be, made in defense of the weekly

${ }^{21}$ For an explanation of the mode by which Industrial agents are compensated, sce TAYLor, op. cit. supra note 6 , at $122-123$. To prevent the agent from writing poor business which would be quickly lapsed his compensation depends in part on his increasing the total number of premium-paying policies on his "debit." ("Debit" means in this connection the territory allotted to him.) How much this contributes to conservative selling by agents is doubtful. The fact still remains that the agent who writes ten policies of which six quickly lapsed is ahead of the agent who writes four policies of which only one lapses. On this point see the Draft by Mr. Sidney Webb of the Report of the Sub-Committec of the Fabian Research Department on Industrial Insurance, cited in id. at 157 .

2 The Case Against Government Life Insurance, infra at p. 127.

${ }^{3}$ The Metropolitan is an exception. It offers a Io per cent discount for payment at the office. 
collection at the home. ${ }^{24}$ First, the Industrial policyholder is unaccustomed to accumulating sums large enough to pay a quarterly or semi-annual premium. It would be difficult for him to effect this accumulation with safety because he does not ordinarily have a bank account. Since the premiums must be collected weekly, the visit of the agent to the home is about as cheap a means of accomplishing this collection as any that could be devised. The Industrial agent is not, after all, a very high-salaried functionary. ${ }^{25}$ Secondly, it is probable that the enormous volume of sales of new Industrial business is made possible, indirectly, by the premium collection system. One of the principal problems of the house-to-house salesman is to secure an entrée into the prospect's home. One recalls in this connection the ingenious devices used by those selling household appliances, -offers of free inspection service, "introductions" from neighbors, gifts of vegetable brushes and the like. The fact that the sale of an Industrial policy involves the purchaser in a commitment of only a few cents and can often, therefore, be effected almost casually, added to the fact that the agent has thereafter an excuse for revisiting the prospect's home, greatly simplifies the merchandising of Industrial insurance. Since the policyholder may lose his enthusiasm for insurance almost as soon as he has paid the first premium, the subsequent calls of the agent may in fact be sales visits though they are tactfully masked as "service." That this merchandizing method is costly is shown by the huge lapse rate in Industrial insurance. But there is little reason to doubt that it has made possible the enormous expansion of the business. ${ }^{26}$ Thirdly, what has just

${ }^{2}$ In this and in other places where I have attempted to outline the arguments which may be advanced for existing company practices I am not attempting to state the official view of any company. To some extent the arguments outlined are based on my own inferences as to the reasons back of existing company practices.

$x$ "A great many individuals have the idea that Industrial insurance is very expensively conducted as compared with Ordinary, and it is frequently stated that the collection of weekly premiums at the homes of the insured adds greatly to the cost of carrying on the business. The real fact of the situation is that when premiums are to be collected in very small units, the house to house collection by the agents of the company represents a real economy over any possible alternative form of collection." Kineke, suprot note 4 , at 26 . It will be noticed that $\mathrm{Mr}$. Kineke assumes that the premiums must be collected.

${ }^{90}$ What is said in the text is not intended as a description of the only sales technique used by Industrial agents, but as that of a method which is always temptingly available. Of course, the better companies make every effort to get their agents to write only business of the type which offers, from the beginning, some likelihood of sticking.

One bit of trade slang is significant in this connection. An Industrial agent who is attempting to sell insurance in homes where he has no entrée through the collection service is said to be "on cold canvass." This phrase expresses the agent's aversion to the effort required to pry into new homes not on his regular collection route, and the non-official literature is filled with admonitions to the agent not to be afraid of "cold canvass." The same psychological twist may also tend to explain why agents sometimes sell insurance to the same family in enormous quantities, sometimes as many as twenty or thirty policies to a family.

"Most experienced agents always carry with them plenty of the most attractive literature issued by their company, advertising cards, or any little novelty which will serve to bring them into the house-for the great art in straight canvassing is to get into the house. . . . Men do not know what it means to ring the door bell of a strange house and inquire about life insurance. That takes courage of the deepdyed order, the courage of the true, determined man who ... quietly makes up his mind to get the best of the difficulties which lie in his path and succeed through surmounting them." ACKERMAN, Industrial Life Insurance (1926) 105, 107. 
been said makes it clear that it is a mistake to regard the weekly call of the agent as representing a collection service merely. The so-called "collection" cost is in part, and perhaps in large part, a selling cost. Fourthly, the weekly visit constitutes a service of some value to the policyholder because it enables him to have answered, conveniently and without delay, any questions he may have concerning his policy. In this way correspondence and visits to the office are eliminated.27 This is particularly important, it is said, when it is recalled that the average Industrial policyholder is-assuming he can read and write-unaccustomed to dealing with business matters by correspondence and not always in a position to arrange his affairs so as to make possible protracted waits and conferences in an insurance office. (The importance of this service, on the other hand, would seem to be considerably diminished by the fact that the Industrial policyholder will seldom have any occasion to ask questions about his policy.) Lastly, through his weekly visit the agent gains an insight into the state of the insured's household which is very valuable to the company. The knowledge thus gained enables the company to guard against speculative insurance and overinsurance. ${ }^{28}$ It enables the company to detect, and often to prevent, "twisting." 29 The insight into the insured's affairs gained through the weekly visit may also be valuable when the time comes to pay the death benefit. The discretion vested in the company under the "facility of payment" clause ${ }^{30}$ is thus guided by an intimate acquaintance with the insured's affairs and a quick and just settlement is made possible. There is no doubt that this last group of considerations weighs very heavily with the companies, at least with their field forces.

One finds occasionally in insurance literature the agent elevated to the position of a veritable godfather to the Industrial household. It has been variously proposed that he include in his duties that of promoting the Will to Prosperity, ${ }^{31}$ of convincing the wage-earner of the futility of strikes, ${ }^{32}$ and of helping to prevent fires during the appropriate Week..$^{33}$ With.all allowance for these extravagances, the fact remains that the weekly visit to the home does simplify many problems of insurance administration. The question is simply whether it is worth what it costs and whether it might not be possible to find other and cheaper means of accomplishing the same results.

In response to the argument that the worker and his family are too improvident to carry life insurance unless wheedled into it by weekly exhortations it may be

${ }^{a}$ See Service in the Home, Industrial Insurance, July, 1931, p. 3.

${ }^{23}$ The weekly visit of the agent makes possible a very inoffensive method of checking on the agent's selection of risks. From time to time the agent may be accompanied on the round of his "debit" by an assistant superintendent or inspector who, while giving every appearance of making a mere friendly call, may ask questions with a view to uncovering speculation or bad underwriting. In practice, however, this kind of inspection takes the form of a sampling process, intended more as a check on the agent's trustworthiness than as an attempt to examine the individual risks written.

20 "Twisting" refers to the practice of inducing the policyholder of one company to give up his policy and take a new policy with the "twister's" company.

${ }^{30}$ See infra page 29.

${ }^{31}$ See Industrial Insurance, Aug., 1933, p. 13.

${ }^{\circledR}$ See id., Aug., r933, p. 3 .

${ }^{\approx}$ Sec id., Oct., 1932, p. I7. 
answered that they have been given very little opportunity to buy life insurance on any other plan. ${ }^{34}$ The Metropolitan is the only company which has tested on a large scale the capacity of the worker to look out for himself in the matter of premium payments. This company offers a Io per cent discount for payments at the office. The extent to which advantage has been taken of this discount indicates that at least some Industrial policyholders possess a modicum of foresight and responsibility. ${ }^{35}$ The success of the plan is all the more remarkable in view of two facts: ( $I$ ) the discount is only available (in the form of a rebate) if the policyholder has been guilty of no default for the period of a year, and (2) the field force of the company, there is reason to suppose, does not exhort the policyholder to take advantage of the plan.

It would be easy to infer from the huge lapse rate in Industrial insurance that it is only by superhuman efforts (including a weekly lecture to each policyholder on the advantages of thrift) that any business is kept on the books at all. This would, however, be a very mistaken conclusion. The high lapse rate arises, not essentially from the improvidence of the great body of policyholders, but from a desperate attempt by Industrial agents to expand the market for their insurance. This is repeatedly recognized in the literature in the statement that lapses arise from business which should never have been written, or that the cause of the lapse lies in the original sale. $^{36}$

There is much reason to believe that there exists a large and willing market for small policies which has no need for pampering in the matter of premium collections. This market undoubtedly owes its existence to the educational effect of decades of activity by Industrial agents, and to an unintended consequence of that activity: that the American worker has developed a taste for expensive funerals. ${ }^{37}$ It is

"I should like to add here a personal observation. A negro Industrial policyholder of my acquaintance at one time regularly returned every Monday night to a former residence, from which she had long since moved, so that the agent might collect from her there the ten cent premium on the regular round of his "debit." Certainly this woman-a domestic servant of no great intelligence-would have been capable of paying her premiums at a downtown office.

EIn 1932 nearly six million dollars was returned to Metropolitan policyholders under this plan. TAYLOR, op. cit. supra note 6 , at $17 \mathrm{I}$.

The lapse rate in Industrial insurance decreases rapidly after the first year and is actually smaller than the rate of Ordinary from the third to ninth years. Kineke, supra note 4 , at 35 . A tremendous number of policies are lapsed within a week or two after issue. Sometimes, indeed, the ostensible insured never pays a premium at all, the first premium being advanced by the agent.

${ }^{37}$ Gebhart's investigation revealed the fact that there has been in recent years a tremendous increase in funeral costs in this country. "During the past twenty-five years the 'demand' for funeral service and merchandise, as limited by the death rate, has remained stationary, while the industry has expanded rapidly. Expansion in total money volume of business has only been possible by selling more goods and more expensive goods to the same number of customers." Gebhart, Funeral, Costs (I928) 267 . Corresponding to this expansion in the volume of business there has been a great increase in the number of undertakers. Id. at 218 .

Commenting on the causes of the increase in burial costs Gebhart says that they are "in part due to the general prosperity of the country, but more particularly to the fact that practically all but the most destitute families carry some life insurance. . . There is ... in this country a vast fund payable at death among practically the entire population. If it were not for these insurance funds, it is exceedingly doubtful if the burial industry in this country would have experienced the rapid expansion it has in the 
probable that this market would never have been brought into existence without the weekly collection in the home It is possible that it cannot be expanded without a retention of that method of premium collection, though there is, as I have said, much reason for supposing that the bulk of it may be retained without the weekly collection. Final judgment on the weekly collection will then depend, if this analysis is correct, on one's judgment as to the utility of Industrial insurance generally. Are the values of this type of insurance sufficient to justify not only the human effort which goes into an attempt to expand its field, but imposing the cost of this effort on the willing and provident policyholder?

Before one condemns the companies it would be well to consider the position they are in. It must be remembered that they are under the embarrassing necessity of "selling" themselves not only to the public but to their agents as well. A company which forced upon its field force a practice which reduced their income, or which merely went against their prejudices concerning the proper way of conducting the business, might soon find itself deserted of selling talent. There are other questions which may properly disturb the company executive. If a company could convert the main body of its policyholders to the system of "office pays," what would be the effect of the ensuing loss of an entrée into the insured's household? What changes in the whole administration of Industrial insurance would it ultimately entail?

In view of the intimate relation between the weekly visit to the home and the whole administration of the Industrial insurance business as it is now conducted ${ }^{38}$ it would probably be inadvisable to attempt a drastic reform of the system by statute. On the other hand, there is much argument for a statute compelling all companies to adopt the Metropolitan's system of discount for payment at the office. This would equalize the conditions of competition among the various companies, and open the way for a gradual evolution in Industrial insurance administration. Its effects would be slow, especially in view of the opposition which might be expected from the companies' field forces. To preserve some of the advantages of the weekly collection system the statute might provide that the policyholder should not be entitled to any discount for payment at the office until after the policy had been in force for one year. This would assure the company of an easy and inoffensive entrée into the

\footnotetext{
past twenty-five years." $I d$. at 222. On the other hand, it should be said that the Metropolitan Life Insurance Company has probably expended more money and effort in an attempt to reduce burial costs than any other single agency in the country. For the rather uncheering history of their cfforts in this direction, see the Introduction to Gebhart's book by Dr. Frankel, id., at vii-xvi. Gebhart's study was itself financed by the Metropolitan.

Of course, an expensive funeral financed out of life insurance may be preferable to a less expensive funeral bought on credit. One social worker reported to Gebhart that it was not an "uncommon matter for a foreign family to cut the living children short on food in order to pay off excessive funeral bills. . . . Insurance on children prevents this kind of hardship, although the undertaker does charge more if there is insurance." Id. at 295.

${ }^{\approx}$ It is not without significance that the English statute regulating Industrial insurance defines the business primarily in terms of the collection system. "For the purposes of this Act, "industrial assurance business' means the business of effecting assurances upon human life premiums in respect of which are received by means of collectors." Industrial Assurance Act, I923, 13 \& I4 GEo. V, c. 8, \$2.
} 
insured's home during a time coinciding with the period usually set in the incontestability clause in the policy.

\section{Some Special Problems of the Insured Wage-Earner}

\section{The Undertaker and the Small Policy}

The fact that the wage-earner can buy only a small amount of insurance not only means that his insurance will cost him more but it also means that he will buy it for different reasons than the man who purchases, say, a $\$ 5,000$ policy. With the wageearner, insurance is at best a marginal expenditure and he is forced to confine his insurance protection to the most obvious risks. The most immediate and perceptible financial loss caused by death consists in the expenses of the funeral. This is the loss which the wage-earner must first attempt to cover, and usually it is the only risk he is able to provide against. At this point there enters another factor of great practical importance. I refer to the fact that undertakers, as a class, are so remarkably free from preconceptions concerning the value of their services. With a diffidence unusual among business men they generally prefer to let the means of the customer control their charges. ${ }^{39}$ This means that if the policy falls between $\$ 50$ and $\$ 500$ there is a very good chance that it will be converted into burial insurance, no matter what the intentions of the insurance company or the policyholder may have been. ${ }^{40}$ The combined effect of these two factors-that the wage-earner cannot afford a big policy and that the undertaker usually manages to absorb the little policy-colors the whole business of Industrial insurance and affects its administration from top to bottom. It is, in fact, generally considered by those who administer the system as a form of burial insurance, though there is nothing in the policy itself which discloses this purpose. ${ }^{41}$

The position of the small policyholder is distinctly improved-so far as the

* A study of the mortician's business methods will be found in Gebhart, Funerar Costs (1928).

${ }^{40}$ As a part of the research which formed the basis for Gebhart's book (stipra note 39) the Metropolitan undertook in 1927 an investigation of nearly 8,000 deaths among its policyholders which yielded the following results: $(r)$ average amount of Industrial insurance carried with the company, $\$ 308$; (2) average cost of burial, $\$ 363$; (3) average ratio of burial cost to insurance, II7.7 per cent. Id. at 274 . These figures may be somewhat misleading since they do not include all insurance carried, but only Industrial insurance with the Metropolitan. The high average cost of burial may be due in part to a few very expensive funerals. There was incidentally revealed a great variation in the situation in different states. In New Jersey the average cost of burial was $\$ 484$, with $\$ 295$ as the average insurance carried; in North Carolina the average cost of burial was $\$ 194$, to an average of $\$ 243$ for insurance.

An investigation by the Prudential Company of 640 claims revealed the following figures: ( $I$ ) average cost of burial, $\$ 362$; (2) average Industrial insurance with Prudential, $\$ 434 ;$ (3) average of all insurance carried, $\$ 672$; (4) percentage of cases where all insurance was insufficient to pay undertakèr's bill, 36; (5) percentage of cases where undertaker's bill left only \$10o or less, 50. The company derived from these figures the conclusion that "Industrial policyholders are generally underinsured," and regarded the study as revealing certain "sales possibilities." Industrial Insurance, Dec. 1932, p. I5.

a This explains why the purchase of Industrial insurance protection, in contrast to Ordinary, is by no means generally confined to the breadwinner of the family. An enormous business is done in infantile policies, many of these being sold in families which are above the wage-earning class in income. See TAYLOR, op. cit. supra note 6, at 22I-242. The fact that Industrial insurance is primarily burial insurance also explains why more than half of the policies are placed on females. Id. at 54 . 
element of cost is concerned-under a scheme of Group insurance. But so far as the danger that the small policy will be converted into undertaker's insurance is concerned, Group insurance offers little or no advantage over Industrial. Conceivably the employer or trade union actually administering the insurance plan may provide some protection against excessive funeral costs.

\section{Premiums and the Business Cycle}

An adequate program of life insurance for the wage-earner would take into account the fact that his income is subject to abrupt termination from time to time through unemployment. ${ }^{42}$ This uncertainty in his income has an obvious effect on his ability to maintain a life insurance policy. Though, as I have pointed out, the high lapse rate in Industrial insurance is probably due chiefly to an effort to expand the market by what might be termed "experimental selling," it is undoubtedly contributed to by the uncertainties of the worker's income. Taylor finds that while, surprisingly enough, there is only a very slight relation between general economic conditions and the sale of new Industrial policies, lapses, on the other hand, tend to follow the curve of employment. ${ }^{43}$

There are two ways of dealing with the problem of lapses due to unemployment. We may attempt to prevent such lapses, or we may assume that they will occur and attempt to reduce their cost to the policyholder.

An attempt to avoid lapses due to unemployment altogether by including in the policy a provision that premiums should be suspended during the time the policyholder is unable to find work would be, pro tanto, a scheme of unemployment insurance and subject to all the difficulties-actuarial, economic, and moral-inherent in any such scheme. On the other hand, a national system of unemployment insurance would not necessarily solve the problem of the life insurance policyholder unless the payments provided were large enough to permit such marginal expenditures as life insurance. If we leave out of account the possibility of some form of unemployment

\footnotetext{
The wage-earner's income may also terminate due to sickness or disability. But since cven for the "middle class" insurance is a marginal expenditure, there is less difference between industrial and Ordinary policyholders in this respect than in most others. The solution in both cases would scem to be the same: some provision for' disability insurance or waiver of premiums during disability. There are, to be sure, certain difficulties which are peculiar' to disability provisions in the small policy. To licep down administration costs disability benefits must be restricted to certain easily definable types of disability. This is, in fact, the practice of the Industrial companies. Sce TAYLoR, op. cit. supra note 6, at 206, and his criticisms of this practice at 207. Also where insurance is taken out on the life of a dependent 'member of the family (as will often be the case where the policy is intended chicfly to cover burial expenses) the usual provision waiving premiums in the case of the disability of the insured is of little utility. Id. at 208.

Group insurance is probably the least satisfactory form of insurance so far as the problem of disability is concerned, since under this form of insurance, unless disability benefits are included, disability may bring about the termination of the insurance by causing the insured to lose his job. See Hanft, Group Life Insurance: Its Legal Aspects, infra at p. 78.

s Op. cit. supra note 6, at 137. During the depression the total amount of Industrial insurance has fallen off considerably, but this is due not so much to a decrease in sales as to an increase in lapses. Id. at 30. Sales of Ordinary insurance, on the other hand, show a closer relation to general business conditions.
} 
insurance, there remain only two relatively ineffective means of reducing lapses caused by unemployment.

We may, in the first place, give the policyholder a period of grace after premium payments are discontinued before his policy lapses. The Industrial policy usually sets a period of four weeks. Obviously this period is so short as to be of little value in the solution of the problem we are here discussing. ${ }^{44}$

Another way of reducing lapses due to unemployment is to induce the worker to build up a reserve against a day of adversity by paying premiums in advance. The non-official literature of Industrial insurance is filled with exhortations to the agent to collect premiums in advance as far as possible, though it is not clear whether this practice is officially promoted by the companies. At any rate, the amount of reserve which can be accumulated in this way is very slight-sufficient perhaps to tide over a spell of seasonable unemployment, but hardly enough tơ brook a major depression.

If buying life insurance protection were like renting a piano there would be no especial reason for concern that inability to find employment should occasionally cause the wage-earner to discontinue his insurance. Insurance could be looked upon as a luxury, appropriate in good times but out of place when the family is on a reduced budget. There are, however, two things about life insurance which prevent us from viewing it in this light. ( $x$ ) From the standpoint of the individual, life insurance is not always available, and when available, is not always available at the same price. With a return of good times the wage-earner may not be able to re-obtain insurance due to the fact that he has become uninsurable meanwhile. Even if he remains physically eligible to insurance he will, under most forms of insurance, have to pay a higher premium on resuming insurance protection because of the increase in his age. (2) In addition to a temporary or permanent loss of insurance protection the lapsing policyholder suffers, under most forms of insurance, a considerable out-ofpocket loss. Most forms of life insurance involve what the salesmen call an "investment feature." The premiums paid in the early years of the policy considerably exceed the actual value of the insurance protection furnished by the policy. It is only on this basis that a company can afford to provide life insurance protection throughout the policyholder's life at a uniform premium, since the actual risk of death increases with each year. It is the reserve built up by the excess of premiums over risk during the early years of the policy which constitutes the policyholder's "investment." Now if this investment were always available without diminution to the withdrawing policyholder-either in the form of cash or extended insurance

"There are objections to lengthening the grace period. (I) A long grace period is a temptation to the improvident. (2) In view of the very high lapse rate in Industrial insurance during the first few wecks of the policy's life a lengthening of the grace period would considerably increase the cost of insurance. (3) If the grace period were too long the practice might develop of buying successive policies paying only one premium on each and thus securing insurance at bargain rates. The grace period as it now stands probably represents a considerable expense to the companies since so many policies are lapsed within a week or two. The insurance provided by such policies is, of course, sold at much less than its actual value. This is another aspect of the cost of the high lapse rate in Industrial insurance to the provident policyholder, since he it is who ultimately finances this bargain rate insurance. 
protection-life insurance could be discontinued without an out-of-pocket loss. But the man whose policy lapses never gets a complete return of his "investment." If his lapse occurs early, before by the terms of the policy "nonforfeiture values" become available, he may get nothing at all. Even if his lapse occurs later and after he has become entitled to "nonforfeiture values" he does not receive a complete return of his "investment" since the companies deduct a varying amount called a "surrender charge." 45

The solution to the problem of eliminating the prejudices which the policyholder suffers by discontinuing his insurance protection would seem to be a form of insurance which (I) involves no selection of risks and hence no possibility that the policyholder whose policy lapses will become uninsurable during the time he remains without insurance (2) is sold for a flat premium bearing no relation to the age of the insured, and (3) involves no reserve value. ${ }^{40}$ In a formal sense, Group insurance meets all of these requirements, and there is, in fact, much to be said for Group insurance for any class of persons whose income is subject to fluctuation and occasional suspension. But the advantages of Group insurance are to some extent illusory. (I leave out of account here Group insurance written on the membership of clubs and unions ${ }^{47}$-a form of insurance which is still, from an actuarial standpoint, in an experimental stage-and consider only Group insurance written on the employees of a particular business firm.) In the first place, Group insurance involves a selection of risks in the sense that only the man who is young and healthy enough to get back his job can reacquire insurance protection. In the second place, the advantages of Group insurance are bought at the cost of certain disadvantages which are peculiar to that form of insurance. Under a plan of Group insurance the employee's insurance protection is tied up with, and wholly dependent upon, a particular employment. When that employment ceases, the employee's insurance ceases with it. ${ }^{48}$ This means that the insurance of the employee depends not only on the stability of his own income, but also upon the stability of his employer's business. This would be true even if the employee paid the whole premium since when the employer closes shop the basis for Group insurance ceases. It also means that the

w The reasons for this deduction are set forth in Maclean, Lrme Insurance (1929) 151-155, and Knight, Advanced Life Insurance (I926) 203-205.

${ }^{45}$ Actually, as has been indicated, it is not the existence of a reserve which causes loss, but rather the fact that it is the practice not to return the entire reserve to the withdrawing policyholder. If a plan of Group insurance permits any person insured to withdraw at any time, the man who pays premiums for a month and then withdraws has probably not paid value for the insurance protection he has received since the overhead connected with insuring him has probably not been covered by his premium. There is, however, no very convenient way of visiting this charge on him. (Actually, the companies writing Group insurance protect themselves against the expenses involved in short-time insurance by providing that no employee is eligible for insurance until he has served out a "probationary period" in his emplo".. . service.) Where a reserve is involved it is easy for the company to deduct the cost of issuing the policy or, as is usually the case, to deduct an even larger sum to put a penalty on lapses and thus prevent an adverse selection of risks.

${ }^{a}$ For a discussion of Group insurance written for the members of labor unions, sce Hedges, Labor's Interest in Group Insurance, infra at p. 94.

${ }^{4}$ See Hanft, Group Life Insturance: Its Legal Aspects, infra at pp. $77-83$. 
reacquisition of insurance protection depends on the employee's ability, not to find work generally, but to find work with an employer who maintains a scheme of Group insurance. The fact that the worker can, on leaving employment, convert his protection into Ordinary life insurance is, as Professor Hanft points out, no very adequate solution of these difficulties. ${ }^{49}$

How adequately is the Industrial policyholder protected against loss arising through the discontinuance of his insurance? How does he compare in this respect with the holder of an Ordinary policy? Here we are struck with the fact that although the uncertainties of his income make it more likely that he will be forced to give up his insurance, the loss which he suffers thereby is, on the average, considerably more than that suffered by the man who allows an Ordinary policy to lapse.

Under most Industrial policies now in force the policyholder cannot get a return of his "investment" in cash until after ten years, and then of course only with the deduction of the "surrender charge." The Ordinary policyholder, on the other hand, may convert his policy into cash at the end of a period varying from one to three years. This difference is founded on, and probably justified by a difference in the habits of the two classes of policyholders. Unpleasant as it may be to have to recognize the existence of such differences, the experience of the companies appears to show that cash surrender values constitute a special temptation to the Industrial policyholder. The curve of Industrial lapses takes a sudden rise so soon as cash surrender values become available. ${ }^{50}$

Taylor has argued against the postponement of the cash surrender value on the ground that it represents an unwarranted attitude of paternalism on the part of the companies. ${ }^{51}$ If the worker wants to convert his policy into cash, that is his affairthe company is not called on to protect him against his weaknesses. But on the other side it may be said that if the period set for cash surrender values were very short, and a large percentage of policies were surrendered for cash, then the companies would be running, not a life insurance business, but a very expensive and wholly indefensible investment service. Some "paternalism" may be necessary to preserve the integrity of the life insurance business itself. ${ }^{52}$

It was during the early years of the depression when thousands of policyholders were converting their policies into cash that the distinction between Ordinary and Industrial policies in regard to cash surrender values was first brought to public

${ }^{0} I d$. at p. 82 .

is Taylor, op. cit. supra note 6 , at $\times 45$.

Id. at 2II-2I2.

As the depression has demonstrated, there is another danger in the cash surrender value beside the temptation to the policyholder's improvidence. In times of financial stringency it may force a rapid and disastrous liquidation of the insurance company's assets. If it is true that the wage-earner's ability to carry life insurance follows the swing of the business cycle, then it is also true that a too liberal granting of cash surrender values in Industrial policies may serve to speed the downward course of the business index in times of depression by forcing a liquidation of the assets of the Industrial companies. Some of the small companies doing both an Ordinary and Industrial business claim that it was the Industrial branch which saved them during the "run" on insurance companies which was finally brought under control by emergency action by the insurance commissioners. 
attention. There was some resentment when Industrial policyholders discovered for the first time what appeared as a discrimination against them. This resentment was, however, short-lived because the larger companies soon adopted a policy of "buying up" Industrial policies before they were eligible by their terms for cash surrender values. This benefit was extended only in cases where the policyholder was in "dire need" and chiefly on the recommendation of the various social agencies. To coordinate the activities made necessary by this service the Big Three companies ${ }^{53}$ established in the early summer of 193I a central office in New York (The Life Insurance Adjustment Bureau)..$^{54}$

As a result of this experience the two largest companies have altered the terms of their policies to permit cash surrender values after five years. ${ }^{65}$ This change took effect January first, 1935, and applies only to policies issued after that date. There is reason to suppose that this change does not proceed from any conviction by company officials that their original view was mistaken but rather from the anticipation of a public demand. ${ }^{56}$

The history of Industrial cash surrenders during the depression brings out two significant things about Industrial insurance: (I) the extent to which administrative discretion, rather than the terms of the policy, controls the benefits available to the insured (the predominance of "paternalism" over "legalism"), and (2) the fact that there may be expected in the future a public demand for an elimination of some of the distinctions between Industrial and Ordinary insurance. This demand will probably be, in large part, ill-advised, but it will constitute none the less an embarrassing problem for the Industrial companies.

The objections to permitting the policyholder to convert his policy into cash have no application where the reserve value of the policy is made available to him, when he discontinues premium payments, not in the form of cash but in the form of extended insurance protection. As a matter of fact under the terms of the usual Industrial policy this return of the policyholder's investment (less the charge for surrender). is made available after three years. ${ }^{57}$ Here again, however, the Industrial policyholder whose policy lapses is, on the average, worse off than the Ordinary policyholder, who may secure non-forfeiture benefits as early as one year after the policy is written. Whether this distinction is justified must remain unexamined

\footnotetext{
* The Metropolitan Life Insurance Company, The Prudential Insurance Company of America, and the John Hancock Life Insurance Company.

The attitude of the smaller companies on the matter of granting special concessions to needy policyholders has apparently not been uniform. The National Convention of Insurance Commissioncrs in April, 1933, "recommended that in any case of great need on the part of an industrial policyholder a cash surrender not exceeding $\$$ roo be allowed by the company." Industrial Insurance, April, 1933, p. 3.

The third member of the Big Three, the John Hancock Company, has for many years in compliance with the laws of Massachusetts granted cash surrender values after five years.

to There had been some agitation for legislation to compel the Industrial companies to grant cash surrender values after five years. See Industrial Insurance, Feb. 1932, p. 3.

"One of the largest companies under "a concession of the Board of Directors" now grants extended insurance on policies lapsing under three years, the period during which premiums must be paid to gain this right depending on the nature of the policy.
} 
here. ${ }^{68}$ It is at least clear that if the reserve were made accessible to the policyholder at an earlier time this would, in view of the fact that the frequency of lapses mounts as we approach the time the policy was issued, considerably increase the cost of insurance to the non-lapsing policyholder. It will be noted that the whole administration of the Industrial business is such as to reward in an unusual degree the man who keeps his policy and, conversely, to penalize in an unusual degree the man who allows his policy to lapse. ${ }^{59}$ This may seem remarkable in view of the fact that most policies are sooner or later lapsed, but it may be explained as due to an effort on the part of the companies to keep down the cost of insurance to the man who diligently keeps up his premium payments.

The reserve value of a lapsed policy may be preserved for the policyholders not only by giving it to him in cash or extended insurance protection but also by permitting him to reinstate his policy after it has lapsed. The usual provision in Industrial policies permits reinstatement at any time within a year after premium default. There are, however, two important limitations on the right to reinstatement which impair its value as a means of preventing prejudice to the policyholder through lapse: (I) the policyholder must remain insurable, and (2) he must pay all back premiums. Both of these limitations on reinstatement have been at times relaxed in practice. The companies often permit reinstatement without cash payment by declaring back premiums a "lien" on the proceeds of the policy. Apparently the requirement concerning insurability has also at times been waived to a limited extent. ${ }^{\text {Co }}$

\section{Life Insurance In Old Age}

It would be no disaster for the average holder of an Ordinary policy if he were deprived of life insurance in his old age. The primary purpose of his insurance is

${ }^{\infty}$ According to Taylor, "The companies assert that the expense of writing a policy is not recouped until after the policy has been in force for three years." Op. cit. supra note 6, at I53. It seems difficult to believe, however, that the time taken to recoup this expense should be greater in Industrial insurance than in Ordinary, which involves for each policy issued a medical examination, an expensive set of records, and a large initial selling commission, none of which is involved in Industrial insurance. The two chief explanations for the higher cost of Industrial insurance-the weekly collection system and a higher mortality rate-represent continuous expenses and do not increase the cost of issuing the policy. The cnly possible reason for a higher cost of issuing the Industrial policy would seem to lie in the high lapse rate, especially during the first few weeks of the policy's life. A high cost of issuing the policy might be arrived at by charging the policyholder who lapses, say, after two years with the risk that he might bave lapsed earlier. The effect of this would be to make the man who lapses, even though his lapse comes relatively late, pay the cost of what I have called "experimental selling."

It should be pointed out that non-forfeiture values, other than cash, are not a particularly good selling point, though some companies have attempted to increase their sales appeal by calling a "paid-up" policy a "free" policy.

29 This is not true if he allows his policy to lapse after one or two premium payments. In that case, because of the four weeks' grace period, he receives insurance at a bargain rate.

The same tendency to award diligence and penalize improvidence finds expression in the postponement of dividends in Industrial insurance. Usually dividends do not become payable until after five years, though one large company shortens the period to three years. See Kineke, supra note 4, at 32.

co ". . . one of the larger companies at least has established the practice of reinstating its lapsed policies irrespective of the state of health of the insured at any time during an additional period of sixteen weeks [after the four weeks permitted by the grace period]." Id. at 34 . 
to protect his dependents against the contingency of his premature death. When that danger has been safely passed his policy loses its function as a protection against risk and becomes merely an investment of an indefinite date of maturity. But for the typical Industrial policyholder, on the other hand-whose primary purpose in taking out life insurance is to cover the costs of his burial, and who is unable in any other way to accumulate a fund for this purpose-the need for life insurance increases rather than decreases with age. And here again the wage-earner is confronted with a pyramiding of handicaps, since his capacity to earn, and therefore his capacity to pay premiums, expires at an earlier date, on the average, than that of the man who occupies a higher rung of the economic ladder.

Since he needs life insurance, or at least burial insurance, after his productive period has ended, the life insurance of the wage-earner ought, ideally, to become paid-up at a relatively early date. There is some recognition of this need in the practice of the larger Industrial companies. Their "whole life" policies are in reality "limited payment" policies since they become paid-up either at the age of 70 or $74^{01}$ There are also available a variety of policies which become paid-up at an earlier age.

So far as providing life insurance protection in old age is concerned Group insurance is worse than useless. Under that plan of insurance the employee of advancing years is visited with a double misfortune, since he loses his insurance at the same time he loses his job. The privilege of converting his insurance into Ordinary has no value to the employee retired on account of age since the premiums would be prohibitively high by the time he has reached the retirement age.

A system of old age pensions would tend to alleviate, though not necessarily to solve, the problem of the wage-earner' in maintaining his life insurance after his capacity to earn has ended.

\section{The Legal Problems of Wage-Earner's Life Insurance ${ }^{62}$}

The principal ethico-legal problem raised by the wage-earner's life insurance may be summarized as the issue of paternalism versus legalism. Legalism offers as its principal virtue that it provides certainty. In those fields where it is necessary that men's actions should be guided by definite rules this virtue is sufficient to commend the legal approach. Real property transfers, the organization of corporations, and other transactions of similar importance demand some legal framework by which men may orient their conduct. But in a field of social practice as informal and undisturbed by premonitions of litigation as that out of which the legal problems of

\footnotetext{
a This is true of the "whole life" policies written by the Big Three. It is not universally true of the policies written by the smaller companies. There is a very considerable variation in the terms of the policies written by the smaller companies, which operate, for the most part, over rather limited areas.

" What follows is chiefly concerned with the law of Industrial insurance. The law' of Group insurance is dealt with in Hanft, Group Life Insurance: Its Legal Aspects, infra p. 70. The present discussion requires the supplementation of Mr. Goldstein's survey of the statutory law of Industrial insurance, infra p. 57 .
} 
wage-earner's insurance arise, the virtue of certainty becomes of less importance. ${ }^{63}$ A definite rule is of little value where it is known that it will be ignored in practice. Here we may best understand legalism as an attempt to circumvent the abuses of paternalism: oppression, corruption, bureaucratic indifference. That the possibility of these abuses is inherent in paternalism is clear. It is not so clear that legalism is certain to cure them. Legalism offers its own peculiar dangers, and these dangers increase as the financial importance of the transaction involved decreases. The juristic machine which legalism constructs to curb individual discretion and indiscretion may turn out to be so complex as to be wholly inaccessible to the man for whose benefit it was intended. Worse than that, the setting up of the machine may aggravate the evils against which it is directed. The establishment of well-intentioned but unworkable legal "safeguards" may serve to relieve those in power from the sense of moral responsibility which previously bridled the exercise of their power.

There runs through the practice of the Industrial companies an assumption that the ordinary processes of the law (litigious and non-litigious) are inappropriate when applied to Industrial policies, whether for the purpose of directing the disposition of the benefits they provide, or for the purpose of settling the disputes which arise out of them. This assumption is, of course, nowhere expressly avowed, but it is implicit in the administration of the business. My own opinion is that the companies have been guided by a sound instinct in preferring the dangers of paternalism to those of legalism. But whatever one's judgment of the practice of the companies may be, one cannot deny the reality of the problem which they have attempted to solve, nor that their solution may serve, if not as an example, then at least as a warning. The most characteristic branch of the law of Industrial insurance-and the only one which we can discuss with any pretense to thoroughness here-is that which centers about what is called the "facility of payment clause."

\section{The Facility of Payment Clause ${ }^{64}$}

This clause, which is found in all Industrial policies and has been occasionally used in other branches of insurance, ${ }^{65}$ gives the insurance company the power to effectuate an informal disposition of the death benefit. Under this clause the company may pay the proceeds of the policy "to any relative by blood or connection by marriage of the insured" or to any other person appearing to the company "to

${ }^{6}$ For a penetrating discussion of the relation between legal certainty and the body of social practice to which the law applies see Llewellyn, Prajudizienrecht und Rechtsprechung in Amerika (i933) $80-86$.

os On the law of the clause see, generally, Note (1932) 32 CoL. L. REv. 1185; Aldrich, Industrial Insurance and the Facility of Payment Clause (1932) 3 DETrort L. REv. 9; McKay, Facility of Payment Clause in Industrial Life Policies, Industrial Insurance, (Dec. 1934), p. 9; 28 A. L. R. 1350; 49 A. L. R. 939; 75 A. L. R. 1435 .

It has been used in so-called Intermediate (monthly-payment) policies, and occasionally in Group certificates. 
be equitably entitled" to the insurance money "by reason of having incurred expense on behalf of the insured, for his or her burial, or for any other purpose."Bo

The clause does not by its terms preclude the naming of a beneficiary, and in many cases the insured does nominate in the policy, or in his application, a person to whom the company is directed to pay the proceeds of the policy. But the clause radically changes the effect of the designation of a beneficiary since it subjects the beneficiary's right to the possibility of being defeated by a payment to some other person who comes within the class described in the clause. ${ }^{67}$ The companies would not normally, of course, except for some good reason, ignore the direction of the insured contained in the designation of a beneficiary, and perhaps the courts would protect the beneficiary against an unreasonable exercise of the power granted in the clause. ${ }^{88}$ Nevertheless, the "right" of the beneficiary in a policy containing the facility of payment clause is something less than a "right" in the ordinary sense, and he is relegated to the position of a person entitled at most to special consideration.

One encounters rather conflicting generalizations concerning the purpose of the clause. The fact is that it serves a number of purposes, some of which will be briefly discussed. As an introduction to this discussion it will perhaps be wise to explain briefly how the power granted in the clause is actually administered by the companies.

\section{The Practice of the Companies under the Clause}

It is significant that although the larger companies publish an elaborate set of written instructions covering most of the phases of their business, the administration of the facility of payment clause is almost totally ignored in these instructions. This may seem a very striking omission in view of the fact that the clause has been referred to as "the very essence of the business." ${ }^{3}$ Yet there are reasons why the companies have been content to let the intramural "law" of the clause go uncodified,

${ }^{\infty}$ For the language of the clause see Hobbs, The Role of the Insurance Commissioner, infra at page

54. There is a slight variation in the wording of the clause as it is used by different companics.

"See Note (I932) 32 CoL. L. Rev. $1185,1 \times 87, \mathrm{n}$. II (a), and in addition to the cases cited there: Watson v. Pilgrim Health and Life Ins. Co., 47 Ga. App. 581, I7I S. E. 226 (1933).

${ }^{8}$ There are judicial intimations that the power granted by the clause may not be exercised arbitrarily, but there is apparently no decision permitting the named beneficiary to recover where the company has paid another person under, the facility of payment clause now commonly used. Sec Note (1932) 32 Col. L. Rev. $x \times 85, \times 187-1188$, n. $1 x, 13-15$, and the dictum in Dorsey v. Metro. L. Ins. Co., 145 So. 304 (La. r933) that the company must act in good faith.

It has occasionally been proposed that where a beneficiary is named the company's power under the clause should be limited to the situation where the beneficiary predeceases the insured or fails to appear within a stated period of time. TAYzoR, op. cit. supra note 6 , at 83; SEventr-THind MassnchusetTs INSURANCE REPORT, Business of 1927 , pt. $\mathrm{II}, \mathrm{p}$. 5. This suggestion has been enacted into law in the District of Columbia. See Section 5 of An Act respecting contracts of Industrial life insurance in the District of Columbia, Public, No. 269, 73d Cong., Ist Sess. (1934). The effect of this section is to protect the beneficiary against an adverse exercise of the power granted by the clause for fiftecn days after the death of the insured. If during that period no claim has been made by or on behalf of the beneficiary the company may then effect settlement under the clause. The wisdom of this statute is, in my opinion, doubtful.

${ }^{\infty}$ Statement of F. G. Dunham, Hearing, supro note 19, at 94 . 
reasons which become apparent when one has studied the actual operation of the clause.

The absence of any authoritative written statement of company practice makes it difficult to determine how the clause is actually administered. However, certain generalizations may be ventured with some confidence. These generalizations are offered here by way of preliminary orientation; some of them will be expanded in the later discussion.

Settlement of the claim is generally effected by a local resident officer of the company whose title varies and who usually performs other functions besides acting as claim agent. The collection agent on whose "debit" the death occurred will usually, because of his knowledge of the home life of the insured, play a more or less active part in the settlement of the claim. Occasionally a case may be referred by the local manager or superintendent to a superior officer, and it may by a process of "reference up" ultimately reach the home office, but this is unusual. Usually settlement is made quickly, sometimes within twenty-four hours after death. In some of the companies the local manager draws a check on funds deposited in a local bank, and the whole case is settled without correspondence with the home office.

Though such a procedure would seem to be authorized by the clause, it is not the practice of the companies to split the insurance money and pay out different sums to different claimants in proportion to their interest or deserts. Except in a very unusual case the company pays in a lump sum to one person. The companies avoid making direct payment to the undertaker. Even though the funeral bill is approved by the relatives and equals or exceeds the policy the company does not ordinarily pay the undertaker, but instead makes the check payable to the beneficiary, or, if no beneficiary is named, to some relative who may be depended on to pay the undertaker's bill.

Where the undertaker's bill is sufficient to absorb the fund no difficulty is likely to arise in the settlement of the policy, since it is generally a matter of indifference who receives the money for the purpose of paying the funeral bill. Difficulty may arise, however, in those cases where there is a substantial surplus over funeral expenses. Here there may be contending claimants to the insurance fund. The company settles these disputes in the best way it can, in a manner which will be described later.

With these very general remarks concerning the company practice under the clause, we now pass to a discussion of the purposes served by the clause.

The Clause as a Device Dispensing with the Necessity for Letters of Administration

The settlement by an insurance company of its liability on a policy need not involve the taking out of letters of administration. Where the policy is payable to a named beneficiary the death benefit is normally paid directly to that person with no 
more formality than is involved in the filling out of the forms provided for proof of death.

Even where the primary purpose of the insurance is to provide for funeral expenses the insured may have his policy made payable to a designated beneficiary with the informal understanding that the money will be used by that person to defray the cost of his burial. There are, however, practical objections to this method, particularly among the class who ordinarily take out Industrial policies. Family estrangements, a divorce or separation, the death or absence of the beneficiarycontingencies of this sort may intervene between the procuring of the insurance and the death of the insured, and may operate to make the policy designating a beneficiary a very unsatisfactory means of covering funeral costs when those costs come actually to be incurred. To this must be added the fact that Industrial policyholders are, according to the experience of the companies, very careless about changing the designation of the beneficiary to suit altered conditions. Because of these difficulties some of the larger companies make every effort to induce the applicant for insurance to make his policy payable to his estate. ${ }^{70}$

If it were not for the facility of payment clause administration would be necessary in those cases where (I) the policy is payable to the insured's estate (as it probably is in considerably more than half the Industrial policies now outstanding) and (2) where the beneficiary predeceases the insured. ${ }^{71}$ In these cases the facility of payment clause saves the expense and delay which would be involved in administration. Of course, it is not to be supposed that if it were necessary to take out letters of administration the primary purpose of the insurance, to provide a burial fund, would be wholly defeated. The undertaker, assured of the existence of the policy and aware of his legal priority, would advance credit pending the appointment of an administrator. But aside from the obvious advantage of saving the expenses ${ }^{72}$

70 The Prudential and Metropolitan companies make no provision either in the policy or in the application for the naming of a beneficiary. If the applicant wishes to name a beneficiary he must usc a separate form provided for that purpose. The right of the beneficiary is made expressly subject to the exercise of the power granted by the facility of payment clause.

There is another reason for this effort to discourage the naming of a beneficiary beside that given in the text. Speculative insurance is a great evil in the Industrial branch. Naturally the speculator wishes to see his, or, perhaps more usually, her name in the policy. To discourage the naming of a beneficiary in the policy is, therefore, to discourage the speculator. Converscly, a policy permitting the naming of a beneficiary has a sales appeal to a certain class. It is possible that some of the smaller companies retain this feature because of its appeal to those who wish to take out insurance on the lives of others. On the other hand, where there is danger of a corrupt entente between the undertaker and the company's agents, something may be said for the policy naming a beneficiary. Whatever the legal status of the beneficiary may be, the company's agents would in practice feel bound to pay the proceeds to him unless some very good and defensible reason could be made out for a contrary course. This tends to eliminate the danger that the undertaker may induce or bribe the selling agent into selecting as payee some person favorably disposed toward his bill.

7 Where the beneficiary predeceases the insured the insurance money normally becomes payable to the insured's estate by virtue of the provisions of the policy. Where the policy fails to cover this contingency the cases are in conflict, some holding that the estate of the beneficiary becomes entitled. See VANCE, Insurance, (2d ed. 1934) 592-595.

Tome of the appellate decisions speak as if the costs of administration would virtually cxhaust a small policy. This seems an overstatement, particularly in view of the fact that there may be available a 
connected with administration there are a number of advantages to the procedure made possible by the clause. First, the delay involved in administration works to the advantage of the unscrupulous undertaker by giving him time to adjust his sliding scale. Secondly, the interposition of the administrator, where he is not an immediate member of the family, may offer another opportunity for a corrupt entente or at least a lack of vigilance in dealings with the undertaker. Thirdly, the legal process of administration not only involves some expense itself but may be the cause of a much greater and perhaps ruinous expense by breeding litigation. Family disputes and the claims of distant relatives often require time and the encouragement of some hungry lawyer to reach their full and litigious heat. The slow-moving processes of the law not only allow ample time for the gestation of controversy, but often unwittingly encourage dispute by reminding the possible claimant of his opportunity. At the risk of overstatement we may say that the facility of payment clause performs a prophylactic function by keeping the insurance fund out of the litigationinfected air of the courthouse.

Whether or not the clause actually achieves all these advantages, it would at any rate seem clear that there is no serious harm in it in those cases where the undertaker's claim exhausts the policy,-unless, indeed, it contributes to enlarging the undertaker's bill, a point which will be discussed later. It has, however, been argued that the justification for the clause ceases where there is a surplus over funeral expenses, and that any such surplus should be disposed of according to the forms of the law. The preliminary draft of the insurance code now being considered in Illinois limits the company's control over the insurance fund to the discharge of funeral expenses and makes any surplus payable to the estate. ${ }^{73}$ The assumption seems to be that with all its expenses, delays, and even possible dangers, administration offers greater assurance than the procedure authorized by the clause that the ultimate disposition of the surplus will be a just one. But is this so clear? From a reading of the appellate reports one would gather that the companies sometimes pay the insurance fund to a woman with whom the insured had been living at the time of his death though he had outstanding, as it were, an undivorced wife. ${ }^{74}$ In such

procedure dispensing with letters of administration where the estate consists of a small claim against a third person. See, e. g., N. C. CoDE (Michie, r93I) $\$ 65$ a, authorizing the payment of any claim of $\$ 300$ or less owed an intestate to the clerk of the court, who is empowered to pay out the proceeds as an administrator would.

${ }^{73}$ Preliminary Draft, Ill. Ins. Code, (Nov. I934), \$238.

7t Sce, e. g., Prudential Ins. Co. v. Howell, 144 Okla. 166, 289 Pac. 734 (1929), and Wilson v. Metro. L. Ins. Co., 239 App. Div. 745, 268 N. Y. Supp. 549 (I934). (Of course if the company knew before it paid the policy that there was any likelihood that the first and only lawful wife would assert her claim, it would probably, as a protection to itself, insist that letters of administration be taken out. But the speedy settlement made possible by the clause reduces greatly the likelihood that the lawful widow will have an opportunity to make any claim until after the policy has been paid.) For another case illustrating the advantages of the flexible principle of settlement mado possible by the clause, sce In re Dickman's Estate, $\mathrm{r}_{42}$ Misc. 207,254 N. Y. Supp. 302 (193I), where the company paid the insured's mother over the claim of a husband who had abandoned her but who later took out letters of administration on her estate. 
cases the deceased and his wife have usually been separated for years, and the interest of the wife in her one-time companion is re-aroused for the first time by the knowledge that he died leaving an insurance policy. Can anyone doubt that in many such cases a payment to the putative second wife may represent a more just disposition than that which would be made by the law, which knows only the "lawful widow"? Or, to take a much more common type of case, an Industrial policy, after being passed about from one member of the family to another, is finally delivered into the possession of the insured's sister, who, being the only one in the family having a steady job, keeps up the premiums. ${ }^{75}$ It is the tacit understanding of the family that she shall receive any surplus over funeral expenses. Under the facility of payment clause the company may recognize this informal transfer of the policy and pay the sister. The administrator, proceeding under the forms of the law, would have more difficulty in recognizing her right, particularly in view of the prohibition of assignment usually contained in the Industrial policy. Perhaps a "friendly" legal proceeding would be recommended as a means of clearing up the doubt, which it would be quite likely to do by exhausting the fund.

So much for the advantages over administration of the procedure under the clause. There are certain limitations on the effectiveness of the clause which prevent it from avoiding the necessity for administration in all cases. These will now be briefly discussed.

In the first place, so far as third persons having claims against the estate are concerned, the procedure under the clause can in no sense be regarded as a substitute for administration. ${ }^{76}$ For example, the company does not assume the rôle of an administrator for the purpose of paying off the ordinary debts of the insured out of the insurance fund. As has been pointed out, it normally pays in a lump sum to one person. This person may in the settlement of the insured's affairs assume a function roughly corresponding to that of an administrator, but it has apparently never been suggested that he, is under legal compulsion to assume any such function. ${ }^{77}$ It has, however, been held that, under ordinary circumstances, the payee of the company may be compelled to surrender any surplus over funeral expenses to the administrator. ${ }^{78}$ The consequence is that in those cases where there is a substantial

\footnotetext{
To "Industrial policies are regarded as family property, available to serve immediate needs upon the death of the insured. Whether a named beneficiary be designated in the contract or not, the premiums are often paid from family funds. These policies are also frequently entrusted to one member of the family after another, as time progresses, each of whom, successively, pays the premiums until such time as absence or other exigency induces further devolution of the stewardship." Brief from Metropolitan Life Insurance Co., Hearing, supra note 19, I12, I16.

${ }^{78}$ The undertaker is perhaps an exception. The company usually looks after his interest much as an administrator would. See the discussion under the heading The Undertaker and the Clause, infra, p. $3^{8}$.

"It has, however, been loosely stated that he is "the agent of the estate," Metro. L. Ins. Co. v. Hightower, 2 II Ky. 36, 40, $276 \mathrm{~S}$. W. 1063, 1064, 44 A. L. R. II58 (1925), or that he is "the trustee of the estate," Smith v. Massie, 93 Ind. App. 582, 179 N. E. 20, 22 (193x).

${ }^{78}$ See the cases cited, note 86 , infra. These decisions may secm inconsistent with the contention
} 
surplus over funeral expenses and where there are either creditors, or relatives more closely related to the insured in legal contemplation than the payee selected by the company, there is always the possibility that letters of administration will be taken out for the purpose of reaching this surplus for the benefit of the estate.

A second limitation on the effectiveness of the clause as a device for avoiding administration lies in the fact that it ceases to be operative if the company, for any reason, denies liability on the policy. If the relatives of the deceased consider it advisable to sue the company it will be necessary to take out letters of administration, since the courts have held that where the policy is made payable to the estate-as is now normally the case in Industrial policies-suit must be brought by the administrator. ${ }^{79}$ An exception is sometimes made in favor of a person who expended money or otherwise changed his position in reliance on a representation by the agent of the company that the clause would be exercised in his favor. He is permitted to sue on the theory that the company has, through its agent, exercised a "present election" to treat him as the payee of the policy. ${ }^{80}$

Thirdly, the clause loses its effectiveness as a means of avoiding administration in those cases where the company, being doubtful of its rights under the clause, insists that letters of administration be taken out as a protection to itself. Certain recent cases have indicated a disposition on the part of the courts to subject the company's action under the clause to judicial review. ${ }^{81}$ With decisions of this sort in mind the company may, for fear of being compelled to pay the insurance money a second time, refuse to pay anyone but the administrator. ${ }^{82}$

made in the text that the procedure under the clause is tof be preferred to administration because of the company's ability to recognize intangible and moral claims. However, as will be explained in the section headed The Clanse as a Device Permitting the Settlement of Disputes without Litigation, as a practical matter, because of the expense of litigation, the company's settlement usually sticks.

${ }^{70}$ See Note (I932) 32 CoL. L. Rev. II85, I I89, n. 25, and in addition to the cases there cited: Yelda v. Western and Southern L. Ins. Co., 99 Pa. Super. 513 (I930); Lewis v. Metro. L. Ins. Co., 17 La. App. 143, 134 So. 699 (193I); Hood v. Prudential Ins. Co., 227 Mo. App. 689, 56 S. W. (2d) I066 (r933); Valenti v. Prudential Ins. Co., 7x F. (2d) 229 (1934); Kelley v. Metro. L. Ins. Co., I55 So. 622 (Ala. 1934); Crump v. Metro. L. Ins. Co., 156 So. 35 (La. I934). But see Life Ins. Co. of Va. v. Newell, 223 Ala. 40I, 404, I37 So. I6, I8 (I93I). Cf. Foryciarz v. Prudential Ins. Co., 95 Misc. 306, I58 N. Y. Supp. 834 (I9I6) permitting suit by an assignee. The suggestion is made in a Note (1932) 32 CoL. L. REv. II85, II90, that this view should be abandoned and that any person who answers the description given in the clause should be permitted to sue. The wisdom of this suggestion seems very doubtful and it is probably based on an overestimate of the expenses involved in administration. (In note 28 therein the statement is made by implication that the expense of administration would "virtually consume" any policy of \$200 or less.)

${ }^{85}$ See Note (I932) 32 Cor. L. Rev. II 85 , II9I, n. 35, and in addition to the cases there cited: Prudential Ins. Co. v. Roberto, 53 R. I. 4I5, 167 Atl. 139, (I933) (representee-payee preferred on interpleader): In re Arnott's Estate, $x_{4} 8$ Misc. 226, $265 \mathrm{~N}$. Y. Supp. 410 (I932) (representee-payee may retain payment against claim of administrator). But see Longley v. Metro. L. Ins. Co., 48 S. W. (2d) 74 (Mo. I932); and of. Kelley v. Metro. L. Ins. Co., I55 So. 622 (Ala. I934).

61 See the cases cited in note 84 , infra.

89 There are other reasons why the company may insist on letters of administration. For example, where it is feared that the creditors of the person who would normally be chosen by the company as payee would exhaust the fund, the company may prefer to pay the administrator. See Brief from Metropolitan Co., Hearing, supra note 19, p. I12, 116. 


\section{The Clause as a Device Permitting the Settlement of Disputes without Litigation}

In the actual administration of the facility of payment clause disputes are infrequent. This is in part due to the fact that the speedy settlement made possible by the clause allows no time for dissensions to ripen. As I have already suggested the clause performs a kind of prophylactic function in this respect. But chiefly thanks are due the undertaker for eliminating friction from the administration of the clause. He seldom leaves enough to cause a fight. ${ }^{83}$

Where, however, the policy is relatively large, or where the insured carried several Industrial policies, so that there is a surplus over the cost of burial, then a dispute may arise between rival claimants. Such a dispute may also arise even in the case of a single small policy where the only claimants are distant relatives who are quite willing to cheat the undertaker of his due. When such disputes arise the company is under no compulsion to settle them and it may fall back on its privilege of paying the estate and insist that letters of administration be taken out. But not infrequently the company attempts to effect a settlement among rival claimants. In such a case the office of the superintendent or manager is converted into an informal tribunal dispensing a kind of cadi justice. Is it a better justice than the parties would get by going to court? It is certainly cheaper and more expeditious. Furthermore, it is arguable that the method employed is more appropriate to the subject matter involved than is the formal and legalistic method of the courts. When it is intelligent and free from corruption it represents the same kind of "fireside equity" which has been found appropriate generally for the solution of small disputes. The method chiefly used is conciliation. When conciliation is merely a euphemism for enforced compromise it has little to recommend it. But as the term is generally used it contemplates a tactful steering of the disputants toward the just solution-which may or may not involve compromise. It should be noted that the insurance official is in a peculiarly advantageous position to accomplish this steering. In addition to the subtle social pressure conferred by his office, he is backed by a very effective sanction in that he can always insist that letters of administration be taken out. When agreement seems difficult to obtain, he may hold this threat over the heads of the disputants. One may imagine the effectiveness of this threat, carrying as it does in the minds of the uninitiated all the fear of the unknown world of officialdom, lawyers, fees, and courts. It should also be noted that the company's settling agent has a unique advantage over most tribunals, official and unofficial, in that he normally possesses, through the collection agent, a more or less intimate knowlege of the insured's household, sometimes extending over a period of years.

Whatever its virtues, it must be recognized that there are certain limitations on the effectiveness of this extra-legal means of settling disputes. In the first place the company's own enthusiasm for its rôle as arbiter may be somewhat dampened by certain decisions declaring that the company may become liable to pay a second time

\footnotetext{
${ }^{\infty}$ See the investigations of burial costs reported in note $4^{\circ}$, supra.
} 
where in the opinion of the court its first settlement was erroneous. ${ }^{84}$ A fear that its settlement may not discharge it of liability may induce the company to play safe and insist on letters of administration. However, the practical effect of these decisions imposing a double liability on the company has probably been very slight. The practice of the companies is not to effect settlement in any case where there is an active contest until a release can be secured from all claimants. The company is, therefore, in no danger of being held to a double liability except where the second claimant makes a belated appearance after the settlement. Accordingly, it is unlikely that these judicial decisions which, in a loose sense, subject the company's settlement to judicial review, greatly affect the practice of the companies or impair their position as extra-legal arbiters.

A second limitation on the company's position as arbiter is to be found in judicial holdings that the settlement effected by the company is not final as between claimants. The way is open to the beneficiary, who has been passed over by the company, to bring suit against the company's payee.85 So, where the policy is payable to the estate, it has been held that the administrator may bring suit against the person paid by the company. ${ }^{86}$ Thus, while the controversy may be ended so far as the insurance office is concerned, it may live on between the claimants and give rise to litigation between them. This may seem seriously to impair the company's position as an arbiter between claimants, since it is an odd tribunal which can only disencumber itself of a dispute and can effect no final disposition as between the disputants. But the limitation is more apparent than real. In actual practice the company's settlement generally ends the controversy. The smallness of the sum involved is usually sufficient to discourage litigation between claimants, to say nothing of the fact that it is unlikely that it will occur to the disgruntled claimant that suit is possible.

It is patent that there are dangers in the assumption of a judicial function by the company. The nature of these dangers is obvious enough not to require discussion here. One particular opportunity for a misuse of the power granted by the clause should however be mentioned. Where the company is denying or seeking to reduce

${ }^{8}$ Zornow v. Prudential Ins. Co., 210 App. Div. 339, 206 N. Y. Supp. 92 (I924), discussed in (x925) 9 MINN. L. Rev. 288; Sylvester v. Metro. L. Ins. Co., 255 Mich. 302, 238 N. W. 234 (I93 I); and see Note (I932) 32 CoL. L. Rev. II 85, II88.

Note (I932) 32 CoL. L. REv., Ir85, II92, n. 44-46.

${ }^{80}$ Note (1932) 32 CoL. L. REv., II 85 , 1192 , n. $47-48$, and see in addition to the cases there cited, In te Schultz' Estate, I52 Misc. 60r, 273 N. Y. Supp. 882 (1934). The principles upon which the courts decide controversies between claimants are not entirely clear. However, it seems generally to be assumed that the person named in the policy as payee-the beneficiary or administrator, as the case may be-is entitled more or less as a matter of course. This attitude is regrettable, especially in those cases where the policy names the administrator or executor of the insured as payee. This provision of the policy is actually inserted to take care of the rare situation where it is impossible to effect settlement without administration and should not be construed as intended to affect the ultimate disposition of the fund. Pcrhaps it is the lack of any other "legal" principle of decision which leads the courts to grant, in a more or less mechanical way, priority to the estate. Courts have to have "reasons"; insurance officials can proceed without them. 
its liability on the policy it acquires an interest in the dispute which ought to disqualify it as a judge between contending claimants. In such a situation it is under the obvious temptation to settle with that claimant who is willing to accept the greatest reduction in the benefit provided by the policy. But since the cases where the company denies liability are infrequent, ${ }^{87}$ and since a settlement for less than the face of the policy with anyone but the payee named in the policy is probably legally ineffective to discharge the company, ${ }^{88}$ the danger here involved is not great.

\section{The Undertaker and the Clause}

In discussing the relation between the undertaker and the facility of payment clause it will be well to separate, provisionally, two questions: (I) Do the companies protect the undertaker to the extent of his "legitimate" claim? (2) Does the clause work to the advantage of the unscrupulous undertaker?

The answer to the first question must depend on inference but it seems to be in the affirmative. The companies are very sensitive about being regarded as collecting agents for the undertaker and, as I have already stated, they do not normally pay the undertaker's bill directly. But this does not mean that there are not ways in which the undertaker's interest may be protected. The simplest of these is to withhold payment from the relatives until the undertaker has been provided for. This seems actually to be the practice in those cases where the policy is made payable to the estate and where there appears some danger that the undertaker's bill will not be paid by the relatives. ${ }^{89}$ It is understandable why this attitude should have grown up. In some cases the undertaker-or more accurately an undertaker- must be given assurance of payment in order to effectuate the intent of the insured. If the company permitted a distant relative to come in and collect the policy, leaving the deceased to a pauper burial, it would certainly be remiss in its trust. Then there are judicial decisions ${ }^{00}$ to the effect that the company may become liable to the undertaker if its agent represents to him that there exists a policy which will provide a fund for funeral expenses-a representation which must often be made in order to

${ }^{57}$ In 1929 the Prudential Company disputed only I.I out of yooo claims in the Industrial branch, as against 5.6 in the Ordinary branch. Brief from Prudential Insurance Co., Hearing, stupra note 19, p. 122 .

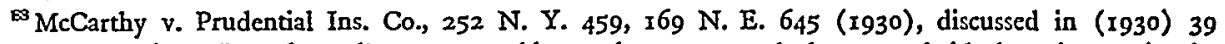
YaLE L. J. 1065. Here the policy was payable to the estate, and the court held that since only the administrator or executor had a legal claim against the company (see note 79, supra) there was no legal basis for a compromise with anyone else.

${ }^{\circ} \mathrm{Cf}$., "In most cases there is no question as to whom the claim should be paid to. If there is a widow, the widow gets it. If there is no widow, very often there is an agreement made that it is to be paid to the undertaker." Statement of James F. Little, representing the Prudential Insurance Co., Hearing, supra note 19, p. 89. Where the policy is payable to a beneficiary the company would be less solicitous for the undertaker's interest. Payment would ordinarily be made to the beneficiary and the undertaker would be left to his own devices. As I have already indicated, this is one advantage of the policy naming a beneficiary.

${ }^{\circ 0}$ Zornow v. Prudential Ins. Co., supra note 84 ; Metro. I. Ins. Co. v. Johnson, x2I Ill. App. 257 (I905). In the latter case the undertaker testified that "he had buried many people who were insured in the appellant company, depending on getting his pay when the claim for benefits under the policy was passed on and allowed." 
save the deceased from a pauper burial. The consequence of these legal and practical considerations is that there has grown up in the business a feeling that the undertaker has a kind of lien on the policy to the extent of his legitimate charges. ${ }^{91}$

The other question, whether the clause works to the advantage of the unscrupulous undertaker, is more difficult to answer. Here everything would depend on the standards of the particular company. Undoubtedly the "paternalism" involved in the clause may be used to protect the family against excessive funeral charges. ${ }^{92}$ It is equally capable of a corrupt diversion in favor of the undertaker. ${ }^{93}$ Final judgment on this aspect of the clause would necessitate a more careful study than has been possible in the preparation of this article. A realistic inquiry into this problem would recognize the difficulty of distinguishing between legitimate and excessive funeral charges and would attempt to discover whether insurance officials do not, with a perfectly good conscience, recognize a kind of normal ratio between funeral bill and insurance policy and thus add their sanction to the undertaker's price-fixing practices.

\section{The Assignment of Industrial Policies}

"Any assignment or pledge of this policy' or of any benefits thereunder shall be void and of no effect." This provision, or language of like import, is to be found in most Industrial policies. A number of reasons have been advanced in justification of it. (I) It is intended as a kind of prophylaxis against disputes and litigation and the delays in settlement which they cause, since assignments are a fertile source of controversy in insurance law. (2) It effects an economy in the administration of the business, and therefore a reduction in premiums. ${ }^{94}$ (3) It protects the policyholder against loan sharks and unscrupulous undertakers.

The provision has been criticized on the ground that "the companies have no

$m$ "If no beneficiary is named . . . the policy would be payable to the insured's estate in which event the undertaker would have first claim." John M. Ehle of the Imperial Life Insurance Co., INDUSTrisL Insurance, Dec. 1934, p. 21.

Da "It is the Agent's duty to endeavor to prevent the unscrupulous undertaker from deceiving or overcharging the policyholder. The rules forbid the assignment of policies or the payment of claims to the undertaker. The Agent can well go further. He can refuse information to the undertaker; he can advise against costly funerals; he can make it easy for claimants to get their papers and their money." Metropolitan Life Insurance Co., Instruction Book for the Exclusive Use of Agents, $\$ 256$.

m "It has been claimed by charity workers who are friendly to our business that our policyholders are subject to gross overcharging by undertakers. . . . And they go on to say that, to some extent, our men are responsible for this in that they recognize undertakers' claims, arrange to have them present, or encourage their presence at the time the claim is paid. Doubtless these charges are exaggerated in some cases and without foundation in others. Most undertakers are men of honor, but some may not be." lbid. See also the somewhat vague reference to abuses in 73d Mass. Insurance Report, Business of 1927. pt. II, p. 4 .

os "If a company had to receive notice of assignments, and refuse . . payment until examination for possible assignments ... was . . made, claims would be greatly delayed and the expenses of the company would rise very materially, as among the great mass of policyholders, with some names repeated hundreds, if not thousands of times, very great care would have to be exercised in order to determine whether or not notice of assignment had been received." Metropolitan Life Ins. Co., op. cit. supra note E7, p. I26. 
right to assume a paternalistic attitude in respect to this or any other provision."05 A statute recently passed by Congress for the District of Columbia provides that nothing contained in any Industrial policy "shall operate to prevent its valid assignment by the insured." $" 96$

It may be questioned whether the provision rendering assignments void really accomplishes anything significant enough to warrant either criticism or legislative reform. The effect of the provision is, in the first place, greatly limited by the legal doctrine that contractual prohibitions of assignment are subject to waiver by the contract-debtor, in this case, the insurance company. ${ }^{97}$ In other words, the company may, but need not, recognize assignments. If objection to the assignment rests in the discretion of the company, and if, as has been judicially indicated, ${ }^{08}$ the company already has the power, under the facility of payment clause, to cut out the assignee, then it may be seen that the provision which purports to render assignments "void" is not so significant as it at first appears. The facility of payment clause is, indeed, the "essence of the business." In confirmation of this it may be noted that there is a similarity, if not, indeed, identity in the judicial limitations which would be imposed on the two powers by which the company may defeat the assignee's right. For example, tacit acquiescence or participation by the agent in a pledge of the policy, which might be construed as a "present election" in favor of the pledgee under the facility of payment clause, ${ }^{99}$ would probably also be construed as a waiver of the prohibition of assignment. ${ }^{100}$ It is significant that the policies now issued by the Prudential Company, which writes about 40 per cent of the Industrial business in the country, contain no express inhibitions on assignment.

In actual practice the companies do recognize assignments, particularly those

${ }^{\infty 6}$ TAYzOR, Op. cit. supra note 6 , at 94 .

${ }^{\circ}$ An Act respecting contracts of Industrial life insurance in the District of Columbia, Public, No. 269, 73d Cong., Ist Sess., (I934) \$\$4-5.

${ }^{5}$ Restatement, Contracts (1932) $\$ 176$; Metro. L. Ins. Co. v. Dunne, 2 F. Supp. I65 (S. D. N. Y. 193I). It is not impossible that the inhibition on assigament would be held altogether void as an improper restraint on commerce. See State Street Furniture Co. v. Armour \& Co., 345 Ill, 160, I77 N. E. 702 (I93I).

${ }^{93}$ Note (1932) 32 CoL. L. REv. 1 r85, 1188 , n. 12. The District of Columbia statute, supra note 96, provides that "the company issuing the policy so assigned shall be discharged of all liability thercon by payment of its proceeds in accordance with its terms, unless before such payment the company shall have written notice of such assignment." The effect of this last proviso is not entirely clear, but it would seem to impose a limitation on the company's power under the facility of payment clause. If so, the statute is significant, not for its invalidation of the prohibition of assignment, but for its effect on the company's power under the facility of payment clause.

${ }^{\infty}$ See note 80 , supra.

100 One obstacle to construing the agent's acquiescence in a transfer of the policy as an clection pr waiver by the company is found in the provision commonly inserted in insurance policies that the agent shall not have power to alter the terms of the written contract. But the problem here is not essentially different whether the facility of payment clause or the prohibition' of assignment is involved. In either case it is possible to argue that the agent's conduct does not "chango the contract" but mercly represents the exercise of a power granted by the contract (La Raw v. Prudential Ins. Co., 56 App. D. C. 199, I2 F. (2d) 140 (1926) or is evidence of the company's own construction of the contract (Foryciarz v. Prudential Ins. Co., 95 Misc. $306,158 \mathrm{~N}$. Y. Supp. 834 (1916) ). Cf. on the problem of waiver and election, Longley v. Metro. Life Ins. Co., 48 S. W. (2d), 74 (Mo. App. I932). 
between members of the same family. An assignment in favor of an undertaker who made it a general practice to obtain assignments of Industrial policies would not be recognized, at least by the better companies. ${ }^{101}$

\section{Legal Devices for Undoing Bad Underwriting}

In any system of life insurance in which participation is voluntary there arises the problem of selecting risks. We have already discussed under the heading WageEarner's Insurance and the Death Rate ${ }^{102}$ those administrative measures-medical examinations, "inspections" and the like-which may be adopted to prevent the writing of insurance on improper risks. That these measures are fallible is obvious. The company's agents may make mistakes, or be imposed on, or may wink at doubtful applications, or even connive at the writing of "death-bed insurance." The consequence is that the companies have not been content to depend upon an administrative prophylaxis against bad underwriting but have inserted in their policies provisions intended to relieve them of liability in those cases where the policy should never have been issued in the first place. The practice is to insert in the policy a provision that it shall become void if the insured at the time of his application suffered from certain named diseases, or was not in "sound health," or failed in some other defined way to meet the test of insurability. ${ }^{103}$ These provisions are, of course, limited by the "incontestability clause" which prevents the company from denying liability on the policy after one or two years from the date of issue.

The problems, legal and ethical, which arise out of these policy provisions are among the most perplexing in the whole field of insurance. The same provision which serves in one case as a necessary protection to the company-and indirectly to the honest policyholder-against the schemes of the speculator, may serve in another case as a trap for the innocent. A provision which serves a useful and unobjectionable purpose in the administration of a company of high standards may cover the

100 "Assignments are forbidden by the policy because they are usually undesirable from the point of view of both the insured and company. Exceptions are, however, made in meritorious cases. . . . The Metropolitan is constantly assailed with demands by undertakers, in the main, for remission of the rule against the recognition of attempted assignments of policy proceeds. . . " Brief from Metropolitan Life Ins. Co., Hearing, supra note 19, p. II4.

${ }^{100}$ Supra p. $x_{3}$.

${ }^{10}$ Statutes commonly provide that representations contained in the application shall not affect the validity of the policy unless a copy of the application is attached to the policy. These statutes usually apply to Ordinary and Industrial insurance alike. Goldstein, $A$ Survey, etc., infra p. 63. Because of these statutes it has become the regular practice in the Ordinary branch to attach a photostatic copy of the application to the policy. On account of the expense involved, this practice has not been followed in the Industrial branch. Instead certain general warranties are printed in the policy itself.

The policies of some companies provide that if the insured shall die of certain named diseases within a certain period the benefits of the policy shall be reduced by a defined amount-sometimes to a fraction of the sum stated in the face of the policy. Though a provision of this kind may, if properly restricted, serve a useful purpose in combatting death-bed insurance, it is doubtful whether stipulations of this sort should be permitted. They render a comparison of the benefits provided by different policies difficultassuming that they are printed in such a way that the prospect will be able to discover them, which is not commonly the case. Some very trickily worded policies of this sort have been sold, policies which because of their comprehensive exemptions of diseases are really little more than accident policies, though they are sold as "life insurance." 
frauds and defaults of some fly-by-night concern. These difficulties are greatly aggravated in any scheme of petty policy insurance. The impracticability of medical examinations, a less competent and perhaps less trustworthy personnel, a less intelligent and often illiterate clientele, the multiplicity of small and recently established companies, the special temptation which small premiums offer the speculatorall these things multiply the difficulties of the problem as it arises in the Industrial branch. No very satisfactory resolution of these difficulties has been hit on, and none is suggested here. It may, however, be useful to analyze certain aspects of the problem. We may distinguish three different solutions of, or more accurately, approaches to this problem.

In the first place it might be proposed that the companies be deprived altogether of the power of undoing their bad underwriting. Suggestions of this sort have actually emanated from responsible sources. In 1927 the Commissioner of Insurance of Massachusetts wrote in his annual report, "Perhaps the best way to cure this situation would be to make the companies more directly responsible for the acts of their agents by eliminating the contestable period altogether, making industrial policies written without medical examination incontestable from date of issue."104 What the consequences of a general adoption of this proposal would be, it is impossible to foresee. Without much question it would necessitate fundamental changes in the administration of the business-with what cost to the policyholder cannot be foretold. ${ }^{105}$ It contains the grave idanger that it might lead to a great increase in speculative and "grave-yard" insurance, a development which would certainly increase the cost of insurance to the honest policyholder if it did not demoralize the whole business.

The second approach to the problem, which might be termed the "legalistic," is to attempt to solve the difficulties of the problem by a precise and clear-cut definition of the rights of the parties. Let us eliminate all vague and general phrases from the policy, for example, the warranty of "sound health." ${ }^{06}$ Let the applicant sign a statement which will contain specific representations: "I have never to my knowledge had tuberculosis," "I have not consulted a doctor during the past five years except in the following cases, to wit," etc. Let legal penalties be imposed to prevent the agent from answering the questions in a perfunctory manner without actually addressing them to the applicant. Let a photostatic copy of the application be attached to the policy so that the policyholder may read it over at his leisure and be in a position to inform the company if it contains any mistakes. Let it be enacted that the applicant shall be held only to good faith, so that his honest mistakes will not count against him. When this situation of clarity and precision has been

${ }^{204}$ Report, supra note 93, p. 4 .

${ }^{100}$ Cf., however, on the costs of "inspection," note i9, supra.

200 "The clause in the policy as it now stands . . . is susceptible of more than one interpretation and should be clarified." TAYLOR, op. cit. supra note 6. p. 85 . 
obtained, let it be left to the courts and juries to determine whether the applicant obtained his insurance by fraud. ${ }^{107}$

This approach is at once the most "reasonable" and the least realistic. As applied to the small policy it involves a gross disproportion of means to end. The purchase of a policy involving an initial expenditure of ten cents cannot be invested with the solemnity of a treaty by any statutory legerdemain. The assumption that a lawsuit is an appropriate means of settling questions arising out of such a policy is equally lacking in realism. ${ }^{108}$ It may, of course, be answered that an actual resort to the courts is not contemplated. Where the rights of the parties are clearly defined and where, therefore, the results of litigation can be foreseen, the mere threat of a law suit suffices. This assumes that the legalistic approach achieves a clear-cut definition of the rights of the parties. Actually the certainty and precision which legalism procures here are almost entirely illusory. To take the most fundamental question, what is "good faith"? The applicant once suffered from a persistent cough, and was told by a doctor that he might have had a "slight touch of tuberculosis." He states in his application that he has never suffered from tuberculosis. Is his representation in "good faith"? Or, suppose the applicant gained the impression that the questions were merely a matter of form and that complete and accurate answers were not expected. Is a false answer by such a person lacking in "good faith"?

Viewed realistically, the net effect of this whole quixotic attempt to introduce certainty into a subject matter which does not permit of certainty is-aside from its incidental effect in making work for the lawyers-to turn the whole problem over to the discretion of juries. ${ }^{109}$ Are juries a proper tribunal to pass on this question? They bring to it neither lack of bias nor special competence. To a natural prejudice in favor of the individual-perhaps a widow-against "the company," there is added, in the jury's mind, the feeling that the company is trying to take back what it has once given. It is unlikely that they will have the insight to realize that an unjust decision against the company may be, in effect, an unjust decision against the honest policyholder. They are unacquainted with the problems of the business. They know nothing of the evil of speculative insurance. Actually the companies are sometimes confronted with perjurious conspiracies involving whole neighborhoods. Insurance officials see sinister possibilities in the future development of this evil. That a whole people can acquire the habit of perjuring themselves in perfect good conscience is amply demonstrated by the personal property tax. There is need here

${ }^{100}$ This was in general the line of attack of those who secured, the enactment recently of a statute affecting Industrial policies written in the District of Columbia. See Hearing, supra note I9, and the Act of Congress cited supra note 96.

${ }^{108}$ The cost of litigation may be reduced-for the litigant-by "vexatious delay statutes" which provide that the successful claimant may recover attorney's fees and a penalty from the insurance company. See Note (1934) $38 \mathrm{HARv}$. L. REv. 319. But these same statutes increase the cost of litigation to the company, and may indirectly contribute to increase the cost of insurance to the main body of policyholders.

${ }^{10}$ Of course, there is here, as elsewhere in the law, some control by courts over juries. But for the most part the courts have been very liberal in allowing issues of fact to go to the jury, and it is usually possible in this field (for the lawyer of any resourcefulness at all) to get the case to the jury. 
from time to time for a vigorous moral cauterization. It is hardly reasonable to expect the jury to provide it.

The third approach to the problem, which may be termed the "paternalistic," is to leave this matter in the hands of the companies. Let them decide which claims are meritorious. This is actually the solution toward which the companies have worked. The warranty of "sound health" contained in Industrial policies is, realistically considered, not a warranty at all, but a device by which the companies attempt to reserve to themselves-subject of course to a minimum of judicial supervisionthe decision when it is wise and just to disallow a claim. ${ }^{110}$

The proposal that the companies be given control over this matter sounds much more shocking than it really is. If the government were to undertake the insurance business there is every reason to suppose that this problem would be taken from juries and given into the jurisdiction of some bureau, with a very restricted right of appeal to the courts. Under a scheme of government insurance that would probably be accepted as the most reasonable disposition of the problem. ${ }^{111}$ There is no reason to suppose that the bureaucracy of the huge mutualized companies is in any way inferior to a governmental bureaucracy. What it loses by working in an atmosphere of "production" and salesmanship, it gains by the checks on indifference and oppression which competition imposes.

But of course the impracticability of this solution, as an official or legislative proposal, is obvious. There exist a great many Industrial companies, of varying standards. The system might work in the case of a company with a long tradition of trusteeship behind it. It would certainly not do to entrust a power of this sort to the shady concern living off the fringes of the business. But who will draw the line between those companies which are capable of this trust and those which are not?

\section{Industrial Insurance and Legislative Reform}

Mr. Goldstein's survey ${ }^{112}$ brings out rather strikingly the extent to which Industrial insurance has been free from statutory regulation. It is not simply that there is an almost complete lack of legislation specially aimed at Industrial insurance. Long statutory chapters regulatory of insurance generally are commonly prefaced by a blanket exemption of Industrial policies. The detailed legislative regulation to which

220 "The purpose of this clause is to protect the honest policyholders from the payment of unjust claims under policies where the insured knew he was uninsurable at the time the contract was issued. Where an individual is not in good health but does not know it the claim is paid without question. Honest policyholders are not affected in any way by the inclusion of this provision. It is intended merely to close the door to fraudulent applicants who are entirely aware of some serious ailment." Kincke, op. cif. supra note 4, p. 34. But though the companies state that the warranty is merely intended as a protection against fraud, they have opposed legislation which would submit to juries the issue of fravd, and have in litigation sought to secure an interpretation of the warranty which would exclude the issue of good faith. Hearing, supra note 19, passim. This attitude does not involve any inconsistency when it is interpreted as an attempt by the companies to preserve for themselves jurisdiction to determine the issue of "fraud."

I11 Of course, a scheme of government insurance which was all-inclusive and compulsory would eliminate this problem and all others connected with the selection of risks.

12 Infra p. 57. 
Ordinary insurance has been subjected, which goes so far as to prescribe even the terms of the policy, has not, for the most part, been extended to the Industrial branch. Why has legislative reform made a detour around the weekly-payment policy? One very simple explanation suggests itself. As Judge Parry has remarked, "the human bottom dog is poorly represented in the great inquest of the nation." 113 Undoubtedly that is a part of the story. Yet there are other considerations which explain the existing situation and which may even to some extent justify it.

The following table may offer one clue to the explanation. It is designed to depict the extent to which the Industrial business is, in particular states, concentrated in the hands of a few concerns or is distributed among a large number of companies. Since no other practicable means of bringing this out seemed available, the table was drawn up to show the geographical distribution of the business of the Big Three companies-Metropolitan, Prudential, and John Hancock. It will be noted that it contains a sampling of states representative of various sections of the country. ${ }^{114}$

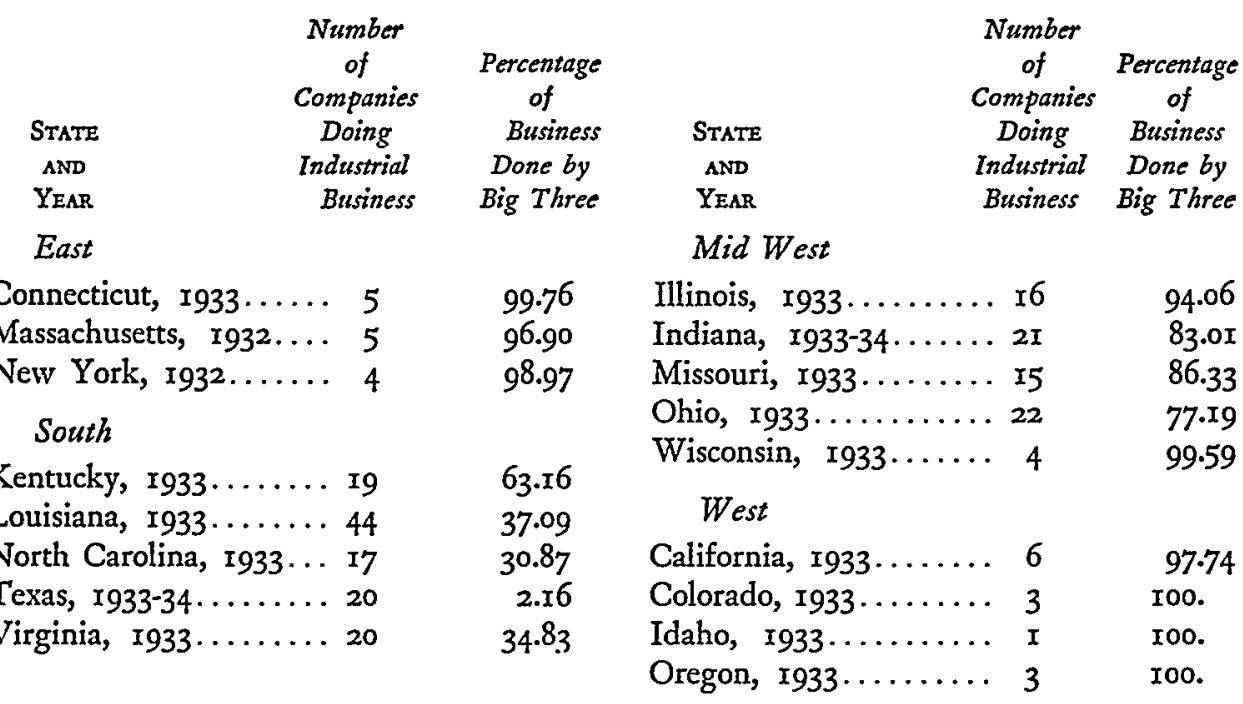

Though the Big Three taken as a unit control about 85 per cent of the Industrial business of the country, their dominance, as the table indicates, is somewhat irregularly distributed. A full explanation for the peculiarities of this distribution cannot be attempted here. It is sufficient for our purposes to notice that those states which have ordinarily taken the lead in legislative reform in insurance (New York and Massachusetts, in particular) are revealed by the table to be those states in which the number of companies writing Industrial business is very small and in which the field

${ }^{213}$ The LAW AND THE POOR (I914) 289.

216 The volume of business was computed on the basis of premiums collected during the year, except in the case of Connecticut, Virginia, and Wisconsin, where it was computed on the basis of the total value of policies in force. In the case of Louisiana the figure for the number of companies includes assessment companies and burial associations. All the computations were based on figures taken from the reports of the various state insurance commissioners. 
is almost completely absorbed by the Big Three. Probably reform legislation has not originated in those states because the situation has not demanded it. The practices of the Big Three are regarded by students of the field as conforming to a high standard, though without the implication that they may not be equalled by those of a substantial number of smaller companies. ${ }^{115}$ For our present purposes, however, it is not necessary to attempt any comparison of company practices, since the intangibles of administration and personnel which they involve are not generally responsive to legislative fiat. In those formal matters which are ordinarily the subject of legislation-policy provisions of various sorts, warranties, non-forfeiture values, and the like-there can be no question that the Big Three have generally taken the lead. Sometimes they have altered the terms of their policies in anticipation of a public demand, and thus eliminated the occasion for legislative reform..$^{110}$ Generally they have kept the provisions of their Industrial policies in as close conformity with those of the Ordinary branch as they considered compatible with the essential differences in the problems of the two fields. Their lead has been followed by a great many of the smaller companies, though there usually intervenes an interval of time before their reforms are generally adopted. In those states where a large number of companies are writing Industrial business, there are usually a few marginal concerns which do not, even in such formal matters as policy provisions, attempt to comply with the higher standards of the business unless they are compelled to do so.

There is, however, an aspect of the problem which is probably much more important, and certainly more objective, than any comparison of the principles and practices of the different companies. I refer to the simple factor of number. Regardless of the character of the companies involved, it is obvious that the need for legislative regulation of certain kinds inevitably increases with the number of companies doing business over a given area. The need for high-pressure sales methods increases with the number of agents operating over a particular territory. The greater the number of companies, the more bewildering the variety of policies offered, and the greater the need for some kind of statutory limitation on policy forms. Coincidentally, the check imposed by a desire to maintain a reputation in a competitive field becomes less, since policyholders can hardly distinguish one company from another. This is particularly true where the agency force of the smaller company consists chiefly of "floaters," so that there is not even an identification of the

\footnotetext{
IIV "They [the Big Three] have played the dominant rôle in the devclopment of what has become a tremendous enterprise. . . . Among them they control nearly eighty-five per cent of the business, which is the more noteworthy when it is understood that approximately one hundred companies are engaged in writing this form of insurance. Not only do they dominate the field, but they also represent the best in principle and practice among Industrial companies. This statement is not meant to exclude or belittle many of the smaller companies that operate in more restricted areas. Several of these are as cfficient and offer benefits equal to those of the larger." TAYLoR, op. cit. sutpra note 6, p. 15.

${ }^{118}$ See, for example, the account of the recent action of the Metropolitan and Prudential companies in regard to cash surrender values, suprd p. 26.
} 
agent with his company. ${ }^{117}$ The resulting confusion leaves an opening for the inevitable "chiseler."

If legislative reform is needed, it is chiefly needed in those states which are not in the habit of originating reforms. There are, moreover, special reasons in this case why they have not overcome their customary inertia. The local companies already suffer a serious handicap in competing with the larger concerns. Often their officials are eager to place their practices on the highest level compatible with their continued development. It may be feared that too stringent statutory regulation might arrest that development.

A more fundamental question is whether legislation is the proper cure for such evils as exist in the Industrial branch. Repeatedly doubt has been intimated in this article whether the proper approach to the problems of petty policy insurance is to be found in "legalism"-with its costs and delays, its assumption of a litigation-wise body of social practice, its reliance on individual initiative in the assertion of the "rights" it creates. For the most part the better approach to the abuses of Industrial insurance will probably be found to be through the insurance commissioner-in other words, through an administrative check on a business which is itself almost entirely "administration." Perhaps an unexpressed conviction of this sort explains the dearth of statutes regulating Industrial insurance. The remarkable growth of the Industrial insurance business has in fact paralleled the progressive emergence of the insurance commissioner as an important factor in the control of the business. Mr. Hobbs' article $^{118}$ conveys some notion of the extensive powers which the commissioner wields or may wield. How wisely those powers are exercised, how much account they take of the interest of the "human bottom dog" will depend on the intelligence and courage of the individual commissioner, on the traditions built up by his predecessors, and upon the legal powers which have been conferred upon him.

Certain things could be achieved by statute. A proposal has already been offered for a statute compelling a discount for the payment of premiums at the office. ${ }^{119}$ In some states statutes restricting the variety of policies issued are urgently needed. Where a policy exempts death due to certain diseases it should be required that a warning of this limitation be printed boldly on the face of the policy. Legislation may also be desirable in some states to enlarge the quasi-criminal powers of the insurance commissioner. But one hesitates to propose a general legislative reform of the law of Industrial insurance. It is easy to foresee what such a general overhauling would be likely to bring. In the first place, it would at an early stage be revealed

177 "As a rule industrial agents are recruited from the wrong class of people, and except with companies like the Metropolitan, the Prudential, and a very few others, they may be regarded largely as 'floaters,' who are in the business only temporarily, or certainly not for a very long period with any particular company, and therefore with no regard for the proper building up of a business which shall be permanent with them as well as with the company." Statement of Lewis A. Irons, Deputy Insurance Commissioner of Georgia, quoted in Hearing, supra note 19, p. 66.

${ }^{11}$ The Rôle of the Instrance Commissioner, infra p. 49. See also, Patterson, The Insurance ComMISSTONER IN THE UNITED STATES (I927).

${ }^{110}$ Supra page 20. 
that there are, under existing practices, important differences between the rights conferred by an Industrial policy and those conferred by an Ordinary policy. There would be an immediate demand for the elimination of these "discriminations." That such a demand would be unwise, that it would, if effectuated, work seriously to the disadvantage of the Industrial policyholder would probably not act as a serious deterrent. A euphemistic and unrealistic attitude characterizes our legislative dealings with economic classes. We generally prefer actual injustice to the poor to an admission in the statutes that poor people exist. Similarly, a general legislative reform would evoke a demand that the policyholder be saved from the "paternalism" of the companies, and the rescuers would probably not stop in their zeal to reflect what the rescue would cost the rescued. In this connection a comparison which Sir Dudley North made of English and Oriental justice is pertinent. "If it be found there [in the Orient] that men truckle under the tyranny of the greater, and bear oppression rather than offend them, here men truckle for fear of the law itself, and let their just right and property go rather than launch into a deluge of officers, counsellors, and forms."120 If we saved the Industrial policyholder from the "tyranny" of the companies could we be sure that we would not let loose on him this "deluge of officers, counsellors, and forms"?

This does not mean that there is not a need for reforms, even for reforms designed to restrict the power exercised by the companies over their policyholders. But it does mean that such reforms must not only be guided by an intimate acquaintance with the problems of the business, but must be steered carefully away from those dangers which I have attempted to summarize in the word "legalism"-dangers which especially threaten any proposal to ameliorate the condition of those at the bottom of the economic scale.

${ }^{100}$ Quoted in COHEN, THE SPIRIT of OUR LAws (I922) I 83. 